\title{
Reconciling Work and Family Life: The Effect of the French Paid Parental Leave
}

\author{
Julie Moschion \\ Melbourne Institute of Applied Economic and Social Research
}

JEL: J13, J18, J22 / KEY WORDS: fertility, Labour Market Participation, Parental Leave, Mothers, Family Life.

\section{ABSTRACT:}

In France, having more than two children has a causal negative impact on mothers' labour supply. The question addressed in this paper is whether the paid parental leave alters this effect. To address this issue, we focus on a reform that modified the conditions in which labour decisions are taken. In July 1994, the Allocation parentale d'éducation was extended to parents of two children (among which one is less than three years old). We show that after the reform, that is, when families of two and more than two children have the same incentive to take a paid parental leave, having more than two children no longer has a negative effect on the participation probability of mothers. In addition, this is particularly true for mothers graduating from secondary school at most, who happen to be the main recipients of the benefit.

\section{Introduction}

In most developed countries where balancing work and family life is currently a major concern, family policies are a key issue. On the one hand, family policies aim at increasing fertility to reach and maintain a level that ensures generation renewal. On the other hand, supporting women's labour supply is desirable from an economic point of view since women's participation in economic activities is a strong factor of economic improvement for developed countries (Conseil d'Analyse Economique's report on gender equality [1999]). In the case of France, the objectives of supporting both fertility and women's participation in the labour market have been put forward by politicians ${ }^{1}$. Even though France has relatively high fertility and women labour force participation rates ${ }^{2}$, fertility has a negative impact on mothers' labour market participation (Moschion [2009]). As a result, when the number of children increases, it becomes harder for mothers to stay in the labour market. In this context, reconciling family and professional responsibilities implies that family policies should resolve the conflict between fertility and labour force participation.

The aim of this paper is to study whether the French paid parental leave (Allocation parentale d'éducation) is consistent with these two objectives, making it easier or not for parents, and especially for mothers, to work and to have the number of children they want. More precisely,

1. In her report for the Prime Minister on how to reconcile work and family life, Deputy Valérie Pécresse argues that in the actual demographic context, "women’s work but also their fertility become essential for our prosperity”.

2. The French total fertility rate decreased between 1970 and 1994, and rose since then: it was 2.47 in $1970 ; 1.94$ in 1980 ; 1.78 in 1990 ; 1.66 in 1994 ; 1.88 in 2000 and 2 in 2008 (Ined). Conversely, women’s labour force participation rate increased since 1975: it was 53.3\% in 1975 for women aged 15 to 64 and 65.3\% in 2007 (Insee). 
we study whether the French paid parental leave alters the impact of the number of children on mothers' labour force participation. The objective is twofold: to understand better why the number of children has a negative impact on mothers' participation in the labour market, and to identify whether the French paid parental leave entertains/breaks the "vicious circle" between fertility and mothers' labour force participation. The French paid parental leave, created in 1985, consists of a monthly benefit provided to parents who reduce or interrupt their activity from the child's birth to its third birthday at the latest ${ }^{3}$. This device is completely egalitarian in theory since fathers as well as mothers can benefit from it. However, in practice the recipients are mostly mothers: in 2005, $97 \%$ of recipients were women. Since the stipend is low and independent of previous wages and since men generally earn more than their spouses, couples who wish to benefit from the paid parental leave usually find it financially interesting that the recipient be the mother (Boyer [2004]). This policy, which explicitly links fertility and mothers' labour force participation behaviours, could naturally alter the causal effect of fertility on mothers' work.

The negative causal impact of fertility on mothers' labour supply differs in time (Foley and York [2005]) and space 4 . These differences could result from cultural or institutional differences. Different family policies, helping parents to more or less balance work and family life, may partly explain these differences. This idea is supported by Bernhardt [1993] and more recently by del Boca et al. [2005] who argue that the negative correlation between fertility and mothers' labour force participation may not be a direct consequence of childbearing, but rather of the process of caring for and raising children. Thus, "the negative association between fertility and labour force participation can be expected to diminish as the conflict between work and family responsibilities is reduced - whether by a change in the nature of work life, shifts in the social organization of childcare, or a combination of the two" (Brewster and Rindfuss [1996]). Assessing the effect of a family policy such as the French paid parental leave on the terms of the trade-off between fertility and labour force participation thus seems relevant.

To the author's knowledge, the question of the link between family policies and the causal effect of fertility on mothers' labour supply has not been addressed in the literature. A first set of studies uses cross-country analysis to evaluate how family policies alter the correlation between fertility and mothers' work (Brewster and Rindfuss [2000], Thévenon [2007]) but they focus on correlations and not on causal effects. A second offset of studies measures the effect of the French paid parental leave on fertility and/or on mothers' labour force participation (Piketty [2005], Laroque and Salanié [2008]), but not its effect on the interaction between fertility and mothers' labour force participation.

The question addressed in this paper raises the major methodological issue of estimating the causal effect of fertility on mothers' labour supply. Fertility may affect mothers' labour supply, but labour supply may also affect fertility, and other observable or unobservable characteristics

3. The benefit can either be full-rate if the parent completely stops working or cut-rate if he works part time. In 1997, the full rate benefit was about 460 euros per month, 300 euros if he worked half time (at most) and 230 euros if he worked between $50 \%$ and $80 \%$ of the time (Afsa [1998]). As a benchmark, the average wage of employed mothers eligible for the benefit was 1087 euros per month (French Labour Force Survey 1997).

4. Whereas the impact of having more than two children on labour supply is significantly negative in the United States (Angrist and Evans [1998]) and in France (Moschion [2008]), it is insignificant in Great Britain (Iacovou [2001]) and in Canada (Ezzaouali [2003]). Comparing French and American results, it appears that the effect of fertility on mothers' participation probability is higher in France. 
may affect both fertility and mothers' labour supply. It is thus delicate to provide unbiased estimates of the causal effect of fertility on mothers' labour supply. In an influential contribution, Angrist and Evans [1998] use the sex of the two eldest siblings as an instrumental variable to estimate the causal influence of having more than two children on mothers' participation in the labour market. American parents with same-sex siblings have a higher probability of having a third child, and in that case, mothers' participation in the labour market is reduced. Their strategy relies on the argument that sex mix is randomly assigned and that it has an effect on participation only through its impact on the probability of having a third child. Using the same strategy on French Data, Moschion [2009] finds that in France having more than two children reduces significantly mothers' participation probability and the number of hours per week they work when they are employed.

To measure the impact of the French paid parental leave, we use the extension of the device to parents of two children (among which one is less than three years old) in July 1994. Before July 1994, only parents with at least three children were eligible for the Allocation parentale d'éducation. In July 1994, it was extended to parents of two children'. This extension has totally modified the financial incentives offered to parents with two children who stop working or reduce their hours worked: if the second child was born before July 1994, its parent receives no benefit, whereas if it was born after, the parent receives a monthly benefit until the child's third birthday. Since this modification was introduced at once, it constituted an exogenous shock that enables us to study how the extension of the Allocation parentale d'éducation to parents of two children has modified the choice between fertility and labour force participation for mothers of two children.

The main contribution of this paper is to estimate the interaction effect between the two regimes of the Allocation parentale d'éducation and the causal effect of having more than two children on mothers' labour supply (instrumented by the sex of the two eldest siblings). More precisely, we examine if, by reducing the differences in treatment between families with two and families with more than two children, the reform also reduced the negative effect of having more than two children on mothers' labour force participation ${ }^{6}$.

We find that, before the extension of the Allocation parentale d'éducation, when the number of children increased from two to more than two, mothers significantly reduced their labour market participation. After the reform, that is, when parents of two and more than two children were in the same position to take a paid parental leave, having more than two children (relative to having only two) no longer had a negative effect on the participation probability of mothers. This was particularly true for graduates of secondary school at most, who were the main recipients of the benefit. Using the birth of twins as an instrumental variable, the results are consistent. The 1994 reform symmetrically increased treatment differences for mothers with one and

5. More recently, in 2004, the whole family policy was reorganised. For a presentation and an analysis of this reform, the reader can refer to Mahieu[2005].

6. This is the type of exercise conducted by Martin [1998]. She opposes the period before 1962 when family policies where particularly generous towards families having two children and the period after 1962 when they were less. She shows that this evolution of family policies was accompanied with an evolution in women's labour force participation rate: the labour force participation rate of women having two children came closer to that of women having one child whereas it moved away from that of women having three children. However, without using instruments to compute unbiased estimates of the effect of fertility on mothers' labour supply; she cannot assure that family policies account for these evolutions. 
mothers with more than one child. Estimating the effect of the reform on the negative impact of having more than one child (instrumented by twins at first birth) on mothers' labour force participation, the results indicate that the reform increased the negative effect of having more than one child on mothers' labour market participation. The results suggest that by creating different incentives among mothers according to the number of children, the Allocation parentale d'éducation explains the major part of the negative effect of fertility on mothers' labour force participation. Thus, this device has negative consequences in terms of balancing professional and family life.

The paper is organised as follows. The next section provides a short discussion of related literature and Section 3 describes the data. Section 4 presents some descriptive statistics. Section 5 presents the model used in the regressions. Section 6 presents the results. Last section concludes.

\section{Related Literature}

A strand of the literature evaluates the impact of family policies on fertility and mothers' labour supply. The economic literature notably studied the impact of parental leaves. For example, Ronsen and Sundström [1999] study the Swedish, Norwegian and Finnish parental leave devices between 1972 and 1992. They argue that the effect of parental leave policies on mothers' labour force participation depends substantially on the characteristics of the leave (length of the leave, amount of the benefit, part-time work possibilities...). Marc [2004] points out that the effect of the French parental leave on mothers' labour supply also depends on the employment conditions of eligible mothers. Studying the Austrian reform of 1990, Lalive and Zweimüller [2009] find that the extension of the maximum duration of the parental leave from until the child's first to its second birthday significantly increased the probability to have an additional child and reduced mothers' time on the labour market. Consistently, using the German reform of 2007, Bergemann and Riphahn [2009] show that increasing the monetary transfer and reducing the duration of the leave shortened women's employment interruptions after child birth.

For France, Piketty [2005] estimates the impact on women's labour supply and fertility of the extension in July 1994 of the Allocation parentale d'éducation to the second child. This reform had considerable effects since the benefit rate among mothers with two children rapidly became extremely substantial: by the end of 1997, more than $40 \%$ of the mothers with two children (of whom one was less than three years old) received the benefit, and more than $30 \%$ received a full-rate benefit (Piketty [2005]). In terms of fertility, Piketty [2005] finds rather moderate effects: the reform could explain at most $20-30 \%$ of the total increase in French fertility observed between 1994 and 2001. On the contrary, the extension of the Allocation parentale d'éducation has induced in three years a major decline in the labour supply of the mothers with two children (of whom one is less than three years old): out of 220000 full rate recipients of the Allocation parentale d'éducation for the second child in December 1997, between 100000 and 150000 mothers would not have interrupted their activity at the second birth if they had not benefited from the paid parental leave. This additional withdrawal movement was particularly concentrated among low skilled mothers. 
Using maximum likelihood estimators based on a discrete choice model, I aroque and Salanié [2008] estimate that the extension of the Allocation parentale d'éducation explains about half of the $7 \%$ increase in the number of births observed in the second half of the 1990s and caused a substantial reduction in the labour supply of eligible women. choné, Ie Blanc and roBert-BoBée [2004] estimate that the suppression of the Allocation parentale d'éducation would increase women's employment rate by 4 percentage points.

The results of these studies clearly indicate that the French paid parental leave has had a negative effect on mothers' labour supply. In these studies however, the potential impact of the reform on the link between fertility and mothers' labour supply is not addressed. The objective of this paper is to better understand the mechanisms affecting the effect of fertility on mothers' activity, and to identify means of reducing this effect so that fertility and mothers' labour force participation could be stimulated simultaneously. We thus study the two elements of differencein-difference estimate separately, that is, the effect of fertility on mothers' labour force participation before the reform on the one hand, and after the reform on the other hand. This shows the effect of having more than two children on mothers' participation when mothers with two and mothers with more than two are in different contexts (before the reform) and when they are in the same context (after the reform). This gives an idea of the net effect of fertility on mothers' labour force participation (after the reform) and the way the Allocation parentale d'éducation contributes to this effect.

Other studies try to identify whether family policies help to balance work and family life, in the sense of reducing the correlation between fertility and mothers' labour supply. They study if, when the correlation at the country level between fertility and mothers' labour force participation becomes less negative, or even positive ${ }^{7}$, this could be attributed to the success of specific family policies. Brewster and Rindfuss [2000] synthesise European and American research on the link between fertility and women's work, and on the impact that various policies may have had on this relationship. They focus on the reversal of the correlation between fertility and mothers' labour supply at the country level: fertility rates tend to be higher in the countries where the participation rate of women in the labour market is also high. According to the authors, this suggests that in some countries, women have succeeded in combining family and professional responsibilities, while in others they have not. Thévenon [2007] studies, for the OECD countries, the link between family policies and countries' performances notably in terms of fertility and women's work. He confirms that a high participation rate of women in the labour market is not contradictory with a high fertility rate, but that this depends on family policies. At the microeconomic level, Kögel [2004] finds that the size of the negative link between fertility and labour force participation varies in time. In particular, he finds that the link was reduced after 1985 in some European countries, precisely at the time when conciliation policies were implemented.

These results suggest that, in step with implemented family policies, the link between fertility and mothers' labour force participation varies. However, using cross-country analysis, these studies do not demonstrate causal relationships. Firstly, because historical and cultural differences between countries may explain why different policies are implemented and also why fertility and mothers' labour supply behaviours differ. In this context, it is hard to establish a causal link

7. The development in the 1990's of a positive correlation between fertility and mothers' labour supply at the country level has been emphasized by several authors (i.e. Bernhardt [1993]; Brewster and Rindfuss [1996]). 
between family policies and fertility-labour supply behaviours. To avoid this issue, we focus on France and use a quasi-natural experiment: the 1994 reform of the paid parental leave. Secondly, these studies focus on the correlation between fertility and mothers' labour supply rather than on a causal effect. Their results are thus delicate to interpret. Mothers with more children are the ones who have a lower labour force participation rate. Because fertility and labour force participation decisions have common determinants, it is extremely difficult to separate the true effect of fertility on labour force participation from 'correlated' effects. We thus propose instrumental variable estimates so as to identify the causal effect of fertility on mothers' labour supply and study how it varies with the institutional context.

\section{Data Description}

The data used in this paper are from the 9 French Labour Force Surveys ( $\mathbf{F}$ S) conducted each year between 1990 and 1998 by the French Statistical Office (insee). The sample of the LES is representative of French metropolitan population aged fifteen and more $(N=135$ 000, sampling rate=1/300). For each respondent, the survey gives birth date, sex, family situation, educational level and participation in the labour market. We also have for each household, the number, sex and birth date of each child living in the household.

Other databases such as the European Community Household Panel (Eurostat) and the Families and employers survey (Ined) also give this information. However, the LFS has the advantage of containing a huge number of observations, which is a necessary condition to obtain precise instrumental variable estimates of the effect of fertility on mothers' labour supply and to study the heterogeneity of this effect across sub-samples. For the same reason we pool the 9 French surveys of the 1990-1998 period. The general censuses of 1990 and 1999 could have been an alternative from the point of view of the number of observations. We do not use them because the first one is available at $1 / 4$ rate and the second at $1 / 20$ rate, which makes the results difficultly comparable.

The selection of the 1990-1998 period results from a trade-off between having the maximum number of observations to perform precise instrumental variable estimates and trying to isolate the effect of the extension of the Allocation parentale d'éducation from other changes or reforms that may have affected the effect of fertility on mothers' labour supply. As a result, 1990-1998 is the largest time span we can use ${ }^{8}$. We do not use previous years because between 1989 and 1990, the LFS was modified, and we do not use subsequent years because the very important reform on work time reduction (Réforme des 35 heures) was announced in June 1998 (the LFS was carried out in March 1998).

We focus on women aged 21 to 35 and having a partner, with at least two children and at least one child aged less than three at the time of the survey $(N=23,407)$. The sample is restricted to women having a partner, who were a priori the only ones concerned by the reform (single mothers who raise a young child could generally benefit from a higher allocation since 1976). Since the benefit was intended only for mothers having at least two children among which one

8. Piketty [2005] stops in 1997, but to compare the effect of having more than two children according to whether mothers had their second child before or after July 1994, we also keep 1998 so that our sample contains enough mothers who had their second child after the reform and also had a third child. 
is less than three years old, our sample is restricted to them. More precisely, we keep mothers having two children whose second child is less than three and mothers having three children or more whose third child is less than three. Therefore the sample selection is not done on the total number of children, which would bias our sample, but rather on the age of the children. We select mothers having at least three children according to the age of the third child rather than the age of the last child, so as to compare the decrease in labour force participation when the second and the third child are in the same age range. Moreover the age of the last child is correlated with the number of children: the greater the number of children, the younger is the last child, and the higher is the probability that the mother is in our sample. In this case, our sample would be biased: mothers with more than three children would be overrepresented compared with mothers with three children.

As Angrist and Evans [1998], because we have information only on children who still live with their parents, we restrict the sample to mothers aged 21 to 35 . This prevents us from underestimating the total number of children at the time of the survey and from introducing errors on the rank of siblings. Women who are more than 35 years old potentially have of-age children, who have a higher probability to live outside the parental home, and thus to be outside of the survey. Including mothers older than 35 would increase the risk of introducing measurement errors on our instrumental variable, i.e. the sex of the two eldest siblings. Selecting mothers aged 21 to 35 having at least two children is not completely neutral and we therefore controlled that selecting the larger sample of mothers aged 21-40 does not alter the results.

\section{Descriptive Statistics}

Among women aged 21 to 35 with at least two children (and one aged less than three), 29\% had a third child (Table I). About 50\% of families had same-sex eldest siblings and a little more than $51 \%$ of first births were boys, which is consistent with national statistics. Twin births represented approximately $0.9 \%$ of second births. The mothers were on average 30 years old and had their first child at 23 and a half years old. $36 \%$ of the mothers had no diploma and about $20 \%$ graduated from college. Compared to the general population, the mothers in our sample had their first child younger and were less educated ${ }^{9}$. These features are not independent of the research question, and may be impacted by either the selection of mothers according to the number of children or to their age (considering that they have at least two children). To test whether our results depend on the fact that we include only young mothers, our results will be compared with those obtained with the sample of mothers aged 21 to 40 . In this extended sample, the mothers were on average older, had their first child slightly later and had more education. In both cases, the results concern only mothers who have at least two children and the results thus cannot be generalised to the whole population. However, because the transition from two to more than two children has become rarer in the last thirty years, this transition is particularly interesting to study (Breton and Prioux [2005]).

9. The average age at maternity (first child) was 26 in 1990 and 27.2 in 1998 (Ined). In the period 1990-1998, among women aged 21 to 35, 30\% had no diploma and 24\% graduated from college (LFS, 1990-1998). 
Table I. - Descriptive Statistics, Women in Couple with at Least two Children and One of the Three First Children Aged Less than Three

\begin{tabular}{|c|c|c|}
\hline \multirow[b]{2}{*}{ Variable } & \multicolumn{2}{|c|}{ Means and (standard deviations) } \\
\hline & 21-35 years old & $21-40$ years old \\
\hline \multicolumn{3}{|l|}{ Fertility characteristics } \\
\hline Number of children & $\begin{array}{c}2.31 \\
(0.50)\end{array}$ & $\begin{array}{r}2.34 \\
(0.51)\end{array}$ \\
\hline Women with more than two children ${ }^{(1)}$ & $\begin{array}{r}0.294 \\
(0.456)\end{array}$ & $\begin{array}{r}0.324 \\
(0.468)\end{array}$ \\
\hline Women whose 1 st child is a boy ${ }^{(1)}$ & $\begin{array}{r}0.514 \\
(0.500)\end{array}$ & $\begin{array}{c}0.513 \\
(0.500)\end{array}$ \\
\hline Women whose 2 nd child is a boy ${ }^{(1)}$ & $\begin{array}{r}0.511 \\
(0.500)\end{array}$ & $\begin{array}{r}0.512 \\
(0.500)\end{array}$ \\
\hline Women whose 1 st and 2nd child are boys ${ }^{(1)}$ & $\begin{array}{r}0.264 \\
(0.441)\end{array}$ & $\begin{array}{c}0.265 \\
(0.441)\end{array}$ \\
\hline Women whose 1st and 2nd child are girls ${ }^{(1)}$ & $\begin{array}{c}0.238 \\
(0.426)\end{array}$ & $\begin{array}{r}0.240 \\
(0.427)\end{array}$ \\
\hline Women whose first two children are same sex ${ }^{(1)}$ & $\begin{array}{r}0.502 \\
(0.500)\end{array}$ & $\begin{array}{r}0.505 \\
(0.500)\end{array}$ \\
\hline 2nd birth is a twin ${ }^{(1)}$ & $\begin{array}{c}0.009 \\
(0.097)\end{array}$ & $\begin{array}{r}0.009 \\
(0.096)\end{array}$ \\
\hline \multicolumn{3}{|l|}{ Sociodemographic characteristics } \\
\hline Age & $\begin{array}{c}30.2 \\
(3.1)\end{array}$ & $\begin{array}{c}31.4 \\
(4.0)\end{array}$ \\
\hline Age at 1st birth & $\begin{array}{c}23.7 \\
(3.4)\end{array}$ & $\begin{array}{c}24.4 \\
(3.8)\end{array}$ \\
\hline No diploma ${ }^{(1)}$ & $\begin{array}{r}0.359 \\
(0.480)\end{array}$ & $\begin{array}{r}0.353 \\
(0.478)\end{array}$ \\
\hline Secondary-school graduates at most ${ }^{(1)}$ & $\begin{array}{r}0.442 \\
(0.497)\end{array}$ & $\begin{array}{c}0.426 \\
(0.495)\end{array}$ \\
\hline College graduates ${ }^{(1)}$ & $\begin{array}{c}0.199 \\
(0.399)\end{array}$ & $\begin{array}{r}0.221 \\
(0.415)\end{array}$ \\
\hline \multicolumn{3}{|l|}{ Labour supply characteristics } \\
\hline Labour market participation ${ }^{(1)}$ & $\begin{array}{c}0.556 \\
(0.497)\end{array}$ & $\begin{array}{c}0.566 \\
(0.496)\end{array}$ \\
\hline Average hours worked per week & $\begin{array}{c}33.9 \\
(9.6)\end{array}$ & $\begin{array}{c}33.8 \\
(9.7) \\
\end{array}$ \\
\hline Number of observations & 23.407 & 28.072 \\
\hline
\end{tabular}

Sample: women with a spouse and at least two children and one of the three first children aged less than three.

Note 1: these are proportions.

Source: labour force surveys 1990-1998, Insee.

"Labour market participation” refers to mothers who are working or unemployed. Although Piketty [2005] uses employment rates, we prefer to use labour force participation rates, i.e. we include the unemployed because the objective is to study how the reform modified the effect of having more than two children on working decisions. An unemployed mother has a priori decided to work, which is not the case of a formally inactive one. Even though the frontier between the two situations is rather vague, and some inactive mothers should actually be part of the active population, it seems more relevant to consider labour force participation rates rather than employment rates, as the latter would lead us to consider the actual employment status of mothers rather than the decision they took. We thus distinguish mothers who chose to work and thus not to benefit from the Allocation parentale d'éducation, from inactive mothers who may receive the benefit. This is consistent with the eligibility rules for the Allocation parentale d'éducation according to which unemployment benefits are not compatible with the parental leave benefit. The labour market participation rate in our sample is about $56 \%$. For the number of hours worked per week, 
the sample is restricted to employed mothers with two children whose number of hours worked per week is between 10 and 60. Employed mothers work on average 34 hours per week.

The labour force participation rates of mothers having one child and that of mothers having three children or more have evolved in the same way between 1990 and 1998 (figure 1). In particular, they did not decrease in 1994-1995. On the opposite, the labour force participation rate of mothers having two children (of whom one is less than three) fell between 1994 and 1998 by more than 17 percentage points (whereas it increased between 1990 and 1994). Only mothers concerned by the reform experience a fall in their labour force participation rates, and this exactly at the time the reform was implemented. As a consequence, the labour force participation rate of mothers having two children comes closer to that of mothers having three children or more (the difference between their labour force participation rates decreases from 37 to 20 percentage points during the period concerned), whereas it moves away from that of mothers having one child (the difference between these two labour force participation rates increases from 13 to 30 percentage points during the period).
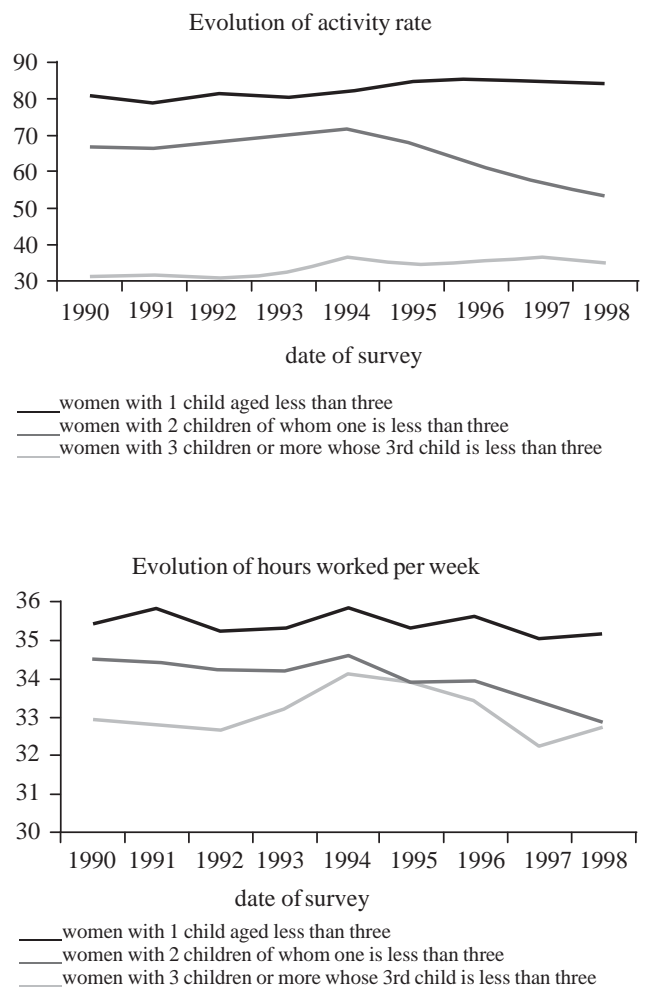

Figure 1. - Annual Evolution of Activity Rates and Average Hours Worked per Week by Mothers According to the Number of Children

Sample: mothers with a spouse aged 21-35 and with at least one of the three first children aged less than three. Source: labour force surveys 1990-1998, Insee.

Sample: Employed mothers with a spouse aged 21-35 and with at least one of the three first children aged less than three. Source: labour force surveys 1990-1998, Insee. 
The evolution of hours worked is not as clear-cut, but the same type of evolution is observed: the average number of hours worked by mothers having two children comes closer to that of mothers having three children or more (the difference decreases from 1.5 to 0.5 hours on average), but it moves away from that of mothers having one child (the difference increases from 1 to 2 hours on average).

These descriptive statistics show that mothers' labour supply decreases as the number of children increases, and that this correlation between fertility and mothers' labour supply changed with the 1994 reform. This is consistent with the idea that the negative effect of having more than two children on mothers' labour supply could to a certain extent come from the Allocation parentale d'éducation.

\section{The Impact of the Paid Parental Leave on the Labour MarketParticipation of Two-child Mothers}

The impact of the paid parental leave on mothers' labour market participation can be estimated with difference-in-differences (Piketty [2005]). Simply comparing the labour force participation rate of mothers with two children before and after the reform does not neutralize the general upward trend in mothers' labour force participation. Difference-in differences estimates solve this problem. The hypothesis is that if the reform had not been implemented, the evolution of the activity rate of mothers with two children would have been the same as that of other mothers with a child aged less than three.

The difference-in-differences estimation of the effect of the Allocation parentale d'éducation on mothers' labour market participation consists in regressing the latter on whether mothers can or cannot benefit from the paid parental leave for their second child (ape2), the fact that they had a third child or not $(x)$ and the interaction between these two variables.

The following equation is estimated:

$$
y_{i}=\alpha_{0}^{\prime} w_{i}+\alpha_{1} s_{1 i}+\alpha_{2} s_{2 i}+\alpha_{3} a p e 2_{i}+\delta_{1} x_{i}+\delta_{2} x_{i}^{*} a p e 2_{i}+\varepsilon_{i}
$$

where $y_{i}$ is a dummy equal to 1 if the mother is active, $x_{i}$ is a dummy equal to 1 if the mother has three children or more, and $a p e 2_{i}$ is a dummy indicating whether the second child was born before or after July 1994 and thus whether its mother could have benefited from the Allocation parentale d'éducation. The sex of child $j$ is noted $s_{j i}$. It is equal to 1 if the child is a boy, 0 if it is a girl. Other covariates $w_{i}$ are age of the mother, age at first birth, age difference between the two first siblings (in months), immigrant status, year-fixed effects and educational level. The age at first birth and the time interval between the first and second birth are correlated with the probability of having a third child (Breton and Prioux [2005]). An early first birth and a short time interval between the two first births may come from a desire to have many children. Young mothers may have a particular profile in terms of background, level of education, nationality, etc. The inclusion of these two variables captures some of the unobservable characteristics that may affect the probability to have a third child and to participate in the labour market. The immigrant status variable is a dummy indicating whether the woman is French born or not. The year-fixed effects are dummies for each year in our sample. They are introduced to 
control for the fact that the economic situation of the different years may affect outcomes. The level of education is introduced with five dummies indicating whether the mother has no diploma, dropped out from secondary-school, graduated from secondary-school, has a bachelors' degree or has a masters' degree.

The interaction variable between "more than two children" $\left(x_{i}\right)$ and "ape2" equals one if the mother had a third child and the second was born after July 1994. The coefficient $\delta_{2}$ gives the impact of the extension of the Allocation parentale d'éducation on mothers' labour market participation.

The estimation of equation 1 suggests that the reform reduced the labour force participation rate of mothers with two children (among which one is less than three-years-old) by 16 percentage points. Piketty [2005] estimates an equation of this type by probit and finds a negative impact of the Allocation parentale d'éducation of between 15 and 22 points. With a different estimation method, specification and sample, we obtain results very close to those of Piketty [2005]. These results are also very close to what is observed with descriptive statistics (Figure 1). Under the hypothesis that, without the reform, the labour force participation rate of mothers with two children would have evolved as that of other mothers, their labour force participation rate would have been $70 \%$ in 1998 . It was actually only $53 \%$, which represents a 17 percentage point difference. Introducing annual fixed effects and individual characteristics as covariates does not substantially modify the estimates.

As a result, the participation decision of mothers with at least two children seems to be highly influenced by financial incentives giving them the opportunity to quit the labour market to raise their young children. This is consistent with Piketty's [2005] result indicating that among the 220000 mothers who had benefited from the full rate benefit for their second child at the end of 1997 , between $50 \%$ and $70 \%$ would not have stopped working without this new financial incentive.

\section{The Impact of Fertility on Mothers' Labour ForceParticipation}

The results of the previous section showed a very strong negative impact of the reform on mothers' labour market participation. In this section, we study more precisely the components of this impact to better understand why fertility negatively affects mothers' labour force participation and to identify means to reduce this effect so as to be able to simultaneously stimulate fertility and mothers' labour market participation. The impact of the Allocation parentale d'éducation estimated in the previous section by the coefficient $\delta_{2}$ can also be written:

$$
E\left(y_{1} / x=1, \text { ape } 2=1\right)-E\left(y_{1} / x=0, \text { ape } 2=1\right)-E\left(y_{1} / x=1, \text { ape } 2=0\right)+E\left(y_{0} / x=0, \text { ape } 2=0\right)
$$

The two first terms give the difference in labour force participation rates of mothers who could benefit from the Allocation parentale d'éducation for their second child depending on whether they have two children or more than two children. The two following terms give the difference in labour force participation rates of mothers who could not benefit from the Allocation parentale d'éducation for their second child depending on whether they have two children or more than two children. 
While in our sample all mothers with at least three children could have benefited from the Allocation parentale d'éducation for their third child ${ }^{10}$, the eligibility of mothers with two children depends on the second child's date of birth. As a consequence, $E\left(y_{1} / x=1\right.$, ape $\left.2=1\right)-E\left(y_{1} / x=0\right.$, ape $2=1$ ) gives the elasticity of mothers' labour force participation in response to the number of children given that they were all eligible for the Allocation parentale d'éducation. On the other hand, $E\left(y_{1} / x=1\right.$, ape $\left.2=0\right)-E\left(y_{0} / x=0\right.$, ape $\left.2=0\right)$ gives the elasticity of mothers' labour force participation to the number of children given that the former could benefit from the Allocation parentale d'éducation for their third child whereas this is not the case of the latter. The second term cumulates the elasticity of mothers' labour force participation in response to the number of children and the effect of the Allocation parentale d'éducation.

The objective of this section is to measure and compare these two elasticities to study whether, when mothers with two and mothers with more than two children are in the same situation, the impact of the number of children is reduced. Since the estimation of these two elements is potentially biased, we use instrumental variables.

\section{VI.1 Model}

The model used in this paper is inspired from Angrist and Evans [1998]. We estimate a two- stage linear probability model in which the second-stage equation links labour supply variables to the endogenous explanatory variables. Two labour supply variables are considered: the first one is a dummy indicating whether the mother participates in the labour market or not (it is equal to 1 if the mother works or is unemployed), and the second one indicates, when she works, the number of hours worked per week. The endogenous explanatory variables are interaction variables between 'more than two children', which is a dummy equal to 1 if the mother has three children or more, and a dummy that indicates whether the second child was born before July 1994 or not, and thus whether its mother could have benefited or not from the paid parental leave for her second child.

The labour supply variables $y_{i}$ are linked to endogenous explanatory variables $\left(x_{i}{ }^{*} a p e 2_{i}\right.$ and $\left.x_{i} *\left(1-a p e 2_{i}\right)\right)$, to the sex of the two eldest children $s_{j i}$ and to other covariates $w_{i}$ by the following equation:

$$
y_{i}=\alpha_{0}^{\prime} w_{i}+\alpha_{1} s_{1 i}+\alpha_{2} s_{2 i}+\alpha_{3} a p e 2_{i}+\beta_{1} x_{i}{ }^{*} a p e 2_{i}+\beta_{2} x_{i}{ }^{*}\left(1-a p e 2_{i}\right)+\varepsilon_{i}{ }^{11}
$$

The interaction variable between "more than two children" $\left(x_{i}\right)$ and "ape2" equals 1 if the mother had a third child and that the second was born after July 1994. The coefficient $\beta_{1}$ gives the effect of passing from two to more than two children on the labour supply of mothers who could benefit from the Allocation parentale d'éducation for their second child. We compare this coefficient with that of the interaction variable between "more than two children" $\left(x_{i}\right)$ and "1 - ape 2 " which equals 1 if the mother had a third child and the second was born before July 1994. The coefficient $\beta_{2}$ gives the effect of passing from two to more than two children on the labour supply of mothers who could not benefit from the Allocation parentale d'éducation for

10. The Allocation parentale d'éducation was created on 1 January 1985. Mothers whose third child was born after this date could receive the benefit for their third child. In our sample, mothers were surveyed starting from 1990, and mothers with three children had a third child aged less than three, who is thus born after the 1 January 1985.

11. The coefficients of this equation are linked to that of equation 1 by the following relations: $\delta_{1}=\beta_{2}$ and $\delta_{2}=\beta_{1}-\beta_{2}$. 
their second child. The dummy variable "ape2" is also included alone in the regressions. The coefficient associated with this variable $\left(\alpha_{3}\right)$ gives the direct effect of the reform on the labour supply variables. The other covariates are the same as in equation 1 . The "same sex" variable is a combination of the sex of the two eldest siblings ${ }^{12}$. As shown in Table I, the probability to have a boy is 0.51 . Thus "same sex" is slightly correlated with the sex of each child. Having boys or girls could have specific effects on the probability to have a third child if parents have a preference for boys or girls. It could also have a direct effect on mothers' labour supply for example if parents raise boys and girls differently; or if the sex of each child is correlated with other determinants of mothers' participation in the labour market. We introduce $s_{j i}$ in all regressions to control for specific effects of the siblings' sex and to correct for potential bias due to the omission of these variables.

To correct for the endogeneity of fertility decisions and to obtain unbiased estimates of the causal effect of fertility on mothers' labour supply, we use second-stage equations which link the endogenous explanatory variables to the instruments. The instruments are interaction variables between a dummy equal to 1 if the two eldest siblings are same sex, and the dummies " $1-$ ape 2 " and "ape2" that indicate whether the second child was born before or after July 1994. The firststage regressions connecting endogenous explanatory variables to the instruments $\left(s s_{i}^{*} a p e 2_{i}\right.$ and $\left.s s_{i}{ }^{*}\left(1-a p e 2_{i}\right)\right)$ are:

$$
\begin{aligned}
& x_{i}{ }^{*} \text { ape } 2_{i}=\pi_{0}^{\prime} w_{i}+\pi_{1} s_{1 i}+\pi_{2} s_{2 i}+\pi_{3} \text { ape } 2_{i}+\gamma_{1} s s_{i} * \text { ape } 2_{i}+\gamma_{2} s s_{i} *\left(1-\text { ape }_{i}\right)+\eta_{i} \\
& x_{i}{ }^{*}\left(1-a p e 2_{i}\right)=\pi_{4}^{\prime} w_{i}+\pi_{5} s_{1 i}+\pi_{6} s_{2 i}+\pi_{7} a p e 2_{i}+\gamma_{3} s s_{i}{ }^{*} a p e 2_{i}+\gamma_{4} s s_{i}{ }^{*}\left(1-a p e 2_{i}\right)+v_{i}
\end{aligned}
$$

The interaction variable between "same sex" and "ape 2 " equals 1 if the mother had same-sex eldest siblings and if the second child was born after July 1994. In equation (3), the coefficient $\gamma_{1}$ gives the effect of having same-sex eldest siblings on fertility for mothers who could have benefited from the Allocation parentale d'éducation for their second child. We compare this coefficient with that of the interaction variable between "same sex" and "no ape2" in equation 4 which equals 1 if the mother had same-sex eldest siblings and if the second child was born before July 1994. The coefficient $\gamma_{4}$ gives the effect of having same-sex eldest siblings on fertility for mothers who could not have benefited from the Allocation parentale d'éducation for their second child.

The use of a two-stage linear probability model is justified by the fact that fertility decisions are endogenous. Thus, an ordinary least squares analysis provides biased estimates of the effect of fertility on mothers' labour supply. Directly comparing the labour supply of mothers with three children or more with that of mothers with two children would lead to confusion between the effect of fertility on labour supply decisions and the possibility that mothers who chose to have three children or more may have specific characteristics that explain both their fertility and activity decisions. Because some of these characteristics may be unobservable, adding control variables in ordinary least squares regressions is insufficient to completely eliminate the endogeneity bias.

To provide unbiased estimates of the effect of fertility on mothers' labour supply, we would like to compare the labour supply of each mother in two situations: the one in which they have

12. It can actually be written: $s s=s_{1} s_{2}+\left(1-s_{1}\right)\left(1-s_{2}\right)$. 
two children with the one in which they have more than two. The problem is that the counterfactual is not observed: if a mother had two children, we do not observe what would have been her labour supply if she had more than two, and if she had more than two, we do not observe what would have been her situation if she had had two. The use of the sex of the two eldest siblings as an instrument for "more than two children" is a solution to this issue. The idea is that the sex of the two eldest siblings is randomly assigned and affects the individual decision of fertility of each mother but has no direct effect on her labour force participation decision. Thus our sample is randomly divided into two groups: the group of mothers with same-sex eldest siblings have a higher probability to have a third child than the group of mothers with different-sex eldest siblings. As a result, the fact that the proportion of mothers who have a third child is higher in the group of mothers with same-sex eldest siblings is statistically independent of individual characteristics, even unobservable. This difference in proportion is used to identify the causal effect of fertility on mothers' labour supply: the effect is negative if, on average, in the group of mothers' with samesex eldest siblings, mothers' labour supply is lower. This method relies on the assumption that if mothers' with different-sex eldest siblings' had had same-sex eldest siblings, their fertility and labour force participation decisions would have been on average identical to those observed in the same-sex eldest siblings' group. When the number of observations is large and the instrumental variable is exogenous, this assumption is verified. When the endogenous explanatory variable is a dummy, another solution to endogeneity issues is the use of simultaneous equations with a probit regression in the first-stage (Heckman [1978]). But following Heckman [1978], when exogenous instrumental variables are available, "Since the linear probability procedure is the simplest one to use, it is recommended". Another argument pleads in favour of linear probability models since no assumptions on the residuals are necessary and according to Heckman and Macurdy [1985], the use of a two-stage linear probability model is justified when one considers simultaneous equations in which the instrument, the endogenous variable and the dependant variable are dummies. Angrist and Evans [1998] as well as Conley [2004] use a model of this type to estimate the impact of fertility on women's labour supply.

\section{VI.2 The Effect of Having Same-sex Eldest Siblings on Fertility}

The results of the estimation of equation (3) are presented in the two first columns of Table II and those of equation (4) in the third and fourth columns. Complete results (including estimates for other covariates) are reported in Appendix I. Mothers whose second child was born before July 1994 represent $77 \%$ of our sample.

In regressions where other covariates are included, the effect on fertility of having same-sex eldest siblings equals 0.028 when the second child was born before July 1994 and it equals 0.022 when the second child was born after July 1994. In other words, having same-sex eldest siblings increases the probability to have a third child by 2.8 percentage points for mothers who could not benefit from the Allocation parentale d'éducation for their second child, and by 2.2 percentage points for mothers who could benefit from the Allocation parentale d'éducation for their second child. Both coefficients are significant at the $1 \%$ level, and the difference between them $(0.006$, standard error 0.008 ) is not statistically significant. Thus, the effect of "same sex" on the probability of having more than two children does not differ according to the second child's date of birth: the reform has not modified the exogenous fertility shock. 
Table II. - Effect of Having Same Sex eldest Siblings on the Probability to have a Third Child

\begin{tabular}{lcccc}
\hline Dependant variable: & \multicolumn{4}{c}{ More than 2 children } \\
\hline & \multicolumn{2}{c}{ 2nd child born $>$} & 1994 & \multicolumn{2}{c}{ 2nd child born $<1994$} \\
\hline Same sex * 2nd child born $>=1994$ & $0.022^{* *}$ & $0.022^{* * *}$ & 0.000 & -0.003 \\
& $(0.006)$ & $(0.006)$ & $(0.000)$ & $(0.005)$ \\
Same sex * 2nd child born $<1994$ & 0.000 & -0.000 & $0.033^{* * *}$ & $0.028^{* * *}$ \\
& $(0.000)$ & $(0.000)$ & $(0.007)$ & $(0.005)$ \\
Other covariates & No & Yes & No & Yes \\
\hline$N$ & 23.407 & 23.407 & 23.407 & 0.407 \\
$R^{2}$ & 0.0413 & 0.052 & 0.4764 \\
\hline
\end{tabular}

Levels of significance: *: $10 \% * *$ : $5 \% * * *: 1 \%$

Sample: women with a spouse aged 21 to 35 with at least two children and one of the three first children aged less than three.

Note: standard errors (in parentheses) are adjusted for potential serial correlation. Other covariates are age, age at first birth, age difference between the two first siblings (in months), educational level, immigrant status, year-fixed effects and sex of first and second child. Main effect for the Allocation parentale d'éducation (variable "ape2") is included in the equation.

Source: labour force surveys 1990-1998, Insee.

The quality of instrumental variable estimates depends on the quality of instruments. In the regressions of endogenous explanatory variables $\left(x_{i}{ }^{*}\right.$ ape $2_{i}$ respectively $\left.x_{i}{ }^{*}\left(1-a p e 2_{i}\right)\right)$ on the two instruments $\left(s s_{i}{ }^{*}\right.$ ape $2_{i}$ respectively $\left.s s_{i}{ }^{*}\left(1-a p e 2_{i}\right)\right)$ with no other covariates, the Fisher statistics are respectively 14 and 21. In the literature, the validation criterion that has emerged is that the Fisher statistic should be strictly higher than 10 (Bound, Jaeger and Baker [1995]). Thus our instruments are powerful and explain well the endogenous explanatory variables.

Our results are consistent with Angrist and Evans [1998] and Breton and Prioux [2005] who also found that the probability of having more than two children is significantly higher when the two eldest children are of the same sex. However, the magnitude of these effects differs slightly: using American data, Angrist and Evans [1998] found that in the nineties, the probability to have a third child was about 7 percentage points higher when the two eldest children were of the same sex, and using French data, Breton and Prioux [2005] found that this difference was about 4.5 percentage points. This variation may come from cultural differences or from the fact that here we distinguish the effect of having same-sex eldest siblings according to the second child's date of birth. When the sample is not restricted to mothers with children aged less than three, Moschion [2009] finds that the global effect of having same-sex eldest children on the probability to have a third child is about 4 percentage points, which is very close to Breton and Prioux [2005].

To further explore the effect of the sex of the two eldest siblings on fertility, we analyse separately secondary-school graduates and college graduates (Table III) ${ }^{13}$. For secondary-school graduates, the effect of "same sex" on fertility does not differ according to the second child's date of birth: it equals 0.024 for births after July 1994 and 0.029 for births before. The effect of the sex of eldest siblings on the probability of having more than two children does not differ according to whether the mother could benefit from the Allocation parentale d'éducation for her second child or not. The effect is negligible for college graduates.

13. The definition adopted for more and less educated mothers may be unusual but is supported by Berger et al. [2006] who show that the probability to take the Allocation parentale d'éducation is identical for mothers with no diploma and secondary-school graduates, whereas it is significantly lower for college graduates. 
Table III. — Effect of Having Same Sex eldest Siblings on the Probability to have a Third Child According to Mothers' Level of Education

\begin{tabular}{lcccccccc}
\hline Dependant variable: & \multicolumn{1}{c}{ More than 2 children } \\
\hline Subsamples: & \multicolumn{3}{c}{ Secondary-school graduates at most } & \multicolumn{3}{c}{ College graduates } \\
\hline & \multicolumn{2}{c}{ 2nd child born $>=$} & 2nd child born $<$ & 2nd child born $>=$ & \multicolumn{2}{c}{ 2nd child born } \\
& \multicolumn{2}{c}{1994} & \multicolumn{2}{c}{1994} & \multicolumn{2}{c}{1994} & $<1994$ \\
\hline Same sex * 2nd child born $>=1994$ & $0.024 * * *$ & $0.024 * * *$ & 0.000 & -0.004 & 0.016 & 0.016 & 0.000 & 0.003 \\
& $(0.007)$ & $(0.007)$ & $(0.000)$ & $(0.006)$ & $(0.012)$ & $(0.012)$ & $(0.000)$ & $(0.009)$ \\
Same sex * 2nd child born $<1994$ & 0.000 & 0.000 & $0.040 * * *$ & $0.029 * * *$ & 0.000 & 0.000 & -0.001 & $0.022^{*}$ \\
& $(0.000)$ & $(0.000)$ & $(0.008)$ & $(0.006)$ & $(0.000)$ & $(0.000)$ & $(0.016)$ & $(0.012)$ \\
Other covariates & No & Yes & No & Yes & No & Yes & No & Yes \\
\hline$N$ & 18.744 & 18.744 & 18.744 & 18.744 & 4.663 & 4.663 & 4.663 & 4.663 \\
$R^{2}$ & 0.0426 & 0.0531 & 0.1197 & 0.4898 & 0.0364 & 0.046 & 0.1065 & 0.3994 \\
\hline
\end{tabular}

Levels of significance: *: $10 \% * *: 5 \% * * *: 1 \%$

Sample: women with a spouse aged 21 to 35 with at least two children and one of the three first children aged less than three.

Note: standard errors (in parentheses) are adjusted for potential serial correlation. Other covariates are age, age at first birth, age difference between the two first siblings (in months), educational level, immigrant status, year-fixed effects and sex of first and second child. Main effect for the Allocation parentale d'éducation (variable "ape2") is included in the equation.

Source: labour force surveys 1990-1998, Insee.

\section{VI.3 Instrumental Variable Estimates of the Effect of Fertility on Mothers' Labour Supply}

Table IV contains the main results of ordinary least squares and two-stage least squares estimations (equation 2). Complete results (including estimates for other covariates) are reported in Appendix II. The labour force participation rate of mothers in our sample is higher among mothers who had their second child before July 1994 (56.4\%) compared to those who had their second child after July 1994 (52.6\%); and when these mothers work, the average number of hours worked per week is higher in the former case (34 against 33).

The first line of $\boldsymbol{T}$ able IV gives the coefficient of the interaction variable between "more than 2 children" and "ape2", and the second line gives the coefficient of the interaction vari- able between "more than 2 children" and "no ape2" for the different estimation techniques and different labour supply variables. Ordinary least squares estimates show that, whatever the date of birth of the second child, mothers who have more than two children participate less in the labour market than mothers with two children. After the reform, that is, when all mothers in our sample were potentially eligible for the Allocation parentale d'éducation, the difference in labour market participation according to the number of children was weaker, but still significantly negative at the $1 \%$ level (17.4 percentage points). Before the reform, when mothers with at least three children could benefit from a paid parental leave for their third child whereas mothers with two children were not eligible, it was inferior by 33.7 percentage points. When they were employed, the number of hours worked by mothers with three children or more was lower than that of mothers with two children only before the reform. These estimates do not characterize the evolution of the causal effect of fertility on mothers' labour supply but only the evolution of the correlation. When the two groups are in the same situation (after the reform), the correlation between having more than two children and mothers' labour supply is reduced. This confirms the graphic analysis: everything else equal, the labour situation of mothers with two children is then closer to that of mothers with more than two children. 
Table IV. — Effect of Having More than Two Children on Mothers' Labour Supply

\begin{tabular}{lcccc}
\hline \hline Dependant variable: & Labour market participation & \multicolumn{2}{c}{ Hours / week } \\
\hline Estimation technique: & OLS & 2SLS Same sex & OLS & 2SLS Same sex \\
\hline More than 2 children * 2nd child born $>=1994$ & $-0.174^{* * *}$ & -0.276 & -0.02 & 4.04 \\
& $(0.028)$ & $(0.602)$ & $(2.37)$ & $(46.35)$ \\
More than 2 children * 2nd child born $<1994$ & $-0.337 * * *$ & $-0.518^{* *}$ & $-0.78^{*}$ & -10.66 \\
& $(0.009)$ & $(0.245)$ & $(0.42)$ & $(13.48)$ \\
\hline$N$ & 23.407 & 23.407 & 7.730 & 7.730 \\
\hline
\end{tabular}

Levels of significance: * : $10 \% * *: 5 \% * * *: 1 \%$

Sample: women with a spouse aged 21 to 35 with at least two children and one of the three first children aged less than three.

Note: standard errors (in parentheses) are adjusted for potential serial correlation. Other covariates are age, age at first birth, age difference between the two first siblings (in months), educational level, immigrant status, year-fixed effects and sex of first and second child. Main effect for the Allocation parentale d'éducation (variable "ape2") is included in the equation.

Source: labour force surveys 1990-1998, Insee.

Instrumental variable estimates (second and fourth columns) give the causal effect of fertility on mothers' labour supply when 'same sex' is used as an instrument. If the second child was born before July 1994, having a third child has a significant negative impact on mothers' probability of working (-51.8 percentage points) whereas if the second child was born after, the impact of a third birth on mothers' working probability is negligible. However, the difference between the estimates is not statistically significant ${ }^{14}$. The effect of having a third child on hours worked is insignificant before and after the reform, but the estimates are imprecise. Passing from two to more than two children has a negative impact on hours worked by mothers (Moschion [2009]), so the insignificance of the results on hours worked is likely to be due to the fact that the sample of employed mothers is too small to identify the effect of fertility on hours worked.

On the whole, two-stage least squares estimates are consistent with ordinary least squares: before the reform, having more than two children entailed a decrease in mothers' labour force participation, whereas after the reform, the decrease was weaker or even null. The impact of having more than two children on mothers' labour force participation, net of the effect of the Allocation parentale d'éducation, is insignificant. The negative effect of fertility on mothers' labour supply before the reform comes from the fact that mothers with two and mothers with more than two children had different incentives to leave the labour market.

\section{VI.4 Has the Reform Caused the Decrease in the Effect of Fertility on Mothers' Labour Supply?}

In this section, we consider other interpretations that may account for our results. On the one hand, the drop in labour force participation rates of mothers' with two children from 1994 could have resulted from specific modifications in their socio-economic characteristics. For example, if their average education level had decreased in this period relatively to that of other mothers; or, if mothers with two children had always been less educated than others, but that the effect of the educational level on the labour force participation probability increased in the period concerned. Piketty [2005] finds that this is not the case, and individual characteristics are included in our regressions to control for such effects.

14. The difference between the two coefficients is $0.518-0.276=0.242$ with a standard error of $\left(0.245^{2}+0.602^{2}\right)^{0.5}=0.650$. 
On the other hand, since we produce instrumental variable estimates, in order to attribute the decrease in the effect of having more than two children on mothers' labour supply to the reform, some assumptions need to be verified for our method to hold. In particular, we want to make sure that the reform has not modified the preferences and characteristics of mothers according to the sex of their eldest siblings. If the reform had altered the effect of having same-sex eldest siblings on the probability of having a third child (preference modification), this change could be the cause of the decrease in our estimates after the reform. In what way could the reform have changed parents' preferences as to the sex mix of their siblings? A possibility could be that since before July 1994, only mothers with three children or more could benefit from the Allocation parentale d'éducation, some mothers could have been incited to have a third child. In this case, the financial incentive would have created opportunistic behaviours consisting in having a third child. This behaviour should then logically be less dependent on the sex of the two eldest siblings before than after the reform, when there was no more financial incentive to have a third child. Actually, we observe the opposite evolution (TaBle II): the effect of "same sex" on the probability to have a third child is insignificantly higher before 1994 than after. This is confirmed by the instrumental variable estimator: $\beta=$ cov (dependant variable, instrument) / cov (endogenous explanatory variable, instrument). As a result, if the decrease in the effect of fertility on labour supply variables $(\beta)$ came from a first-stage effect, we should observe an increase in the effect of eldest siblings' sex on fertility (denominator), which is not the case. The reform does not seem to have modified parents' preferences.

The financial incentive to have a third child, relative to having two, disappears in 1994. If there had been opportunistic fertility behaviours, we would then have observed a decline in fertility rates of parity three from 1995 among two-child mothers (whose youngest child is less than three). This is not the case (Figure 2): fertility rates decrease quite substantially in 1994, but that tendency started in 1993 and reversed in 1995. Consequently it cannot be attributed to the extension of the Allocation parentale d'éducation.

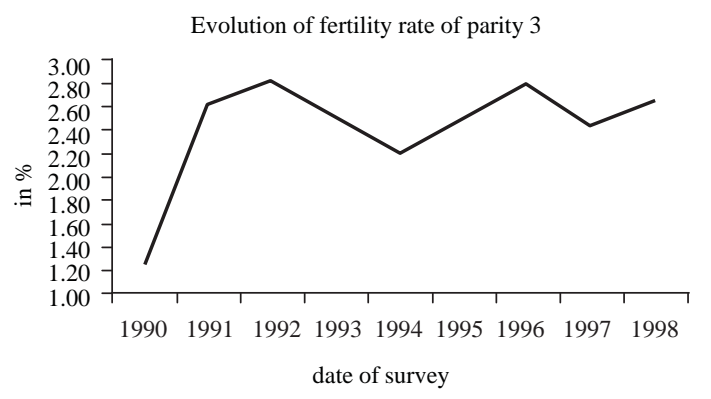

Figure 2.

Sample: mothers with a spouse aged 21-35 with at least two children and one of the three first children aged less than three.

Reading: the fertility rate of parity three gives the proportion of mothers in the sample that had a third child a given year. In 1995, among mothers with a spouse aged 21-35 with two children, 2.5\% had a third child.

Source: labour force surveys 1990-1998, Insee. 
Similarly, the reform could have created opportunistic behaviours consisting in having a second child. In this case, we would have observed an increase of second births among mothers with one child starting from 1995. As shown in Figure 3, this is not the case. Apart from lower levels in 1990 and 1993 and a higher level in 1997, the fertility rate of parity 2 is stable. As a result, the reform does not seem to have modified fertility behaviours as already emphasized by Piketty [2005]. It thus seems reasonable to suppose that the populations of mothers having a second child before and after the reform are identical.

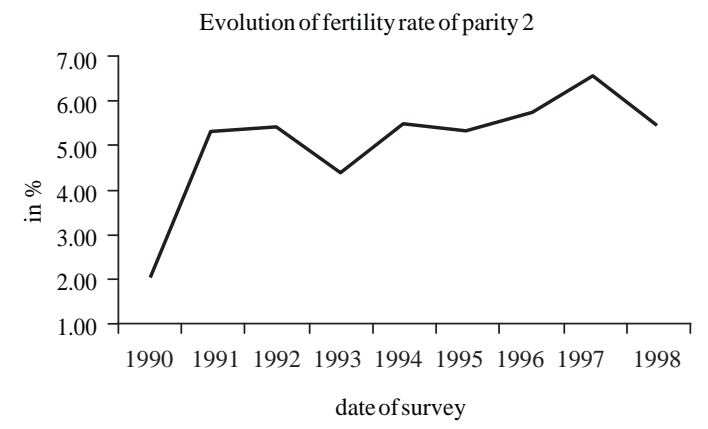

Figure 3.

Sample: mothers with a spouse aged 21-35 with at least one child and one of the two first children aged less than three. Reading: the fertility rate of parity two gives the proportion of mothers in the sample that had a second child a given year. In 1995, among mothers with a spouse aged 21-35 with one child, 5.3\% had a second child. Source: labour force surveys 1990-1998, Insee.

In addition, we checked that no differences appeared in demographic characteristics between mothers having same-sex siblings and those having different-sex siblings, before and after the reform (Table V). Even though mothers' characteristics evolved between the two periods, this evolution was identical for mothers having same-sex siblings and those having different-sex siblings. Small differences appear before the reform for the age at first birth and the time span between the two first births but these differences are inferior to one month. The effect of "same sex" on the probability to have more than two children and on labour supply is thus not explained by differences in mothers' individual characteristics.

\section{VI.5 Mothers' Level of Education}

Another way to check that the negative effect of the third child on mothers' labour supply truly comes from the incentives induced by the Allocation parentale d'éducation, is to study the evolution of this effect on subpopulations. Recipients of the Allocation parentale d'éducation are mostly poorly educated women (Afsa [1998], Berger et al. [2006]). Consequently, the effect of having more than two children on mothers' labour supply should have been significantly negative for poorly educated mothers before the reform, whereas it should have been insignificant after the reform. For highly educated mothers, who benefited less from the Allocation parentale d'éducation, the effect of having more than two children on their labour supply should have been weaker whatever the date of birth of their second child. 
Table V. - Differences in means for demographic variables by 'same sex'

For mothers that could not benefit from the Allocation parentale d'éducation for their second child

\begin{tabular}{lcccccccccc}
\hline & Age & $\begin{array}{c}\text { Age at first } \\
\text { birth }\end{array}$ & $\begin{array}{c}\text { Time span } \\
\text { between } \\
\text { the first } \\
\text { 2 births }\end{array}$ & $\begin{array}{c}\text { French } \\
\text { natives }\end{array}$ & $\begin{array}{c}\text { Age at } \\
\text { the end } \\
\text { of studies }\end{array}$ & Diploma & $\begin{array}{c}\text { 2nd birth } \\
\text { after 1994 }\end{array}$ & $\begin{array}{c}\text { Number of } \\
\text { children }\end{array}$ & 3rd child \\
\hline SS & 29.99 & 24.74 & 44.12 & 0.90 & 19.35 & 0.24 & 1.00 & 2.06 & 0.061 \\
& $(0.062)$ & $(0.064)$ & $(0.520)$ & $(0.006)$ & $(0.090)$ & $(0.008)$ & $(0.00)$ & $(0.005)$ & $(0.005)$ \\
DS & 30.07 & 24.76 & 45.12 & 0.90 & 19.33 & 0.24 & 1.00 & 2.04 & 0.039 \\
& $(0.060)$ & $(0.063)$ & $(0.513)$ & $(0.006)$ & $(0.103)$ & $(0.008)$ & $(0.00)$ & $(0.004)$ & $(0.004)$ \\
Diff & -0.081 & -0.019 & -0.994 & 0.001 & 0.022 & 0.005 & 0.00 & $0.024^{* * *}$ & $0.022^{* * *}$ \\
& $(0.086)$ & $(0.090)$ & $(0.731)$ & $(0.008)$ & $(0.137)$ & $(0.012)$ & $(0.00)$ & $(0.006)$ & $(0.006)$ \\
\hline
\end{tabular}

Levels of significance: *: $10 \% * *: 5 \% * * *: 1 \%$

Sample: women with a spouse aged 21 to 35 with at least two children and one of the three first children aged less than three who could not benefit from the Allocation parentale d'éducation for their second child.

Note: standard errors are reported in parentheses. "SS" designates mothers with same sex eldest siblings and "DS" designates mothers with different sex eldest siblings.

Source: labour force surveys 1990-1998, Insee.

For mothers that could not benefit from the Allocation parentale d'éducation for their second child

\begin{tabular}{|c|c|c|c|c|c|c|c|c|c|}
\hline & Age & $\begin{array}{l}\text { Age at } \\
\text { first birth }\end{array}$ & $\begin{array}{l}\text { Time span } \\
\text { between } \\
\text { the first } \\
2 \text { births }\end{array}$ & $\begin{array}{l}\text { French } \\
\text { natives }\end{array}$ & $\begin{array}{l}\text { Age at the } \\
\text { end of } \\
\text { studies }\end{array}$ & $\begin{array}{c}\text { Educational } \\
\text { level }\end{array}$ & $\begin{array}{l}\text { 2nd birth } \\
\text { after } \\
1994\end{array}$ & $\begin{array}{c}\text { Number } \\
\text { of } \\
\text { children }\end{array}$ & 3rd child \\
\hline SS & $\begin{array}{c}30.23 \\
(0.033)\end{array}$ & $\begin{array}{l}23.47 \\
(0.034)\end{array}$ & $\begin{array}{c}40.71 \\
(0.255)\end{array}$ & $\begin{array}{l}0.90 \\
(0.003)\end{array}$ & $\begin{array}{c}18.41 \\
(0.053)\end{array}$ & $\begin{array}{l}0.19 \\
(0.004)\end{array}$ & $\begin{array}{l}0.00 \\
(0.000)\end{array}$ & $\begin{array}{l}2.41 \\
(0.006)\end{array}$ & $\begin{array}{l}0.38 \\
(0.005)\end{array}$ \\
\hline DS & $\begin{array}{c}30.17 \\
(0.033)\end{array}$ & $\begin{array}{c}23.38 \\
(0.036)\end{array}$ & $\begin{array}{c}41.63 \\
(0.270)\end{array}$ & $\begin{array}{l}0.90 \\
(0.003)\end{array}$ & $\begin{array}{c}18.41 \\
(0.055)\end{array}$ & $\begin{array}{c}0.19 \\
(0.004)\end{array}$ & $\begin{array}{l}0.00 \\
(0.000)\end{array}$ & $\begin{array}{l}2.37 \\
(0.006)\end{array}$ & $\begin{array}{l}0.35 \\
(0.005)\end{array}$ \\
\hline Diff & $\begin{array}{l}0.063 \\
(0.047)\end{array}$ & $\begin{array}{l}0.089 * \\
(0.050)\end{array}$ & $\begin{array}{l}-0.920 * * \\
(0.371)\end{array}$ & $\begin{array}{r}-0.005 \\
(0.004)\end{array}$ & $\begin{array}{r}-0.002 \\
(0.077)\end{array}$ & $\begin{array}{r}-0.005 \\
(0.006)\end{array}$ & $\begin{array}{l}0.000 \\
(0.000)\end{array}$ & $\begin{array}{l}0.034 * * * \\
(0.008)\end{array}$ & $\begin{array}{l}0.033^{* * *} \\
(0.007)\end{array}$ \\
\hline
\end{tabular}

Levels of significance: *: $10 \% * *: 5 \% * * *: 1 \%$

Sample: women with a spouse aged 21 to 35 with at least two children and one of the three first children aged less than three who could not benefit from the Allocation parentale d'éducation for their second child.

Note: standard errors are reported in parentheses. "SS" designates mothers with same sex eldest siblings and "DS" designates mothers with different sex eldest siblings.

Source: labour force surveys 1990-1998, Insee.

For both sub-samples, OLS estimates of the effect of fertility on mothers' labour supply decrease when mothers had their second child after the reform (Table VI). For secondary- school graduates, having a third child decreased the probability of labour market participation by 35 percentage points if the second child was born before the reform, whereas it decreased only by 21 percentage points if it was born afterwards. These effects are both significant at the $1 \%$ level. For college graduates, the effect of a third birth, which is significant at the $1 \%$ level if the second child was born before the reform, becomes insignificant if it was born afterwards. These results suggest again that, when the elasticity of mothers' labour market participation to the number of children is purged from the effect of the Allocation parentale d'éducation, this effect becomes weaker or insignificant.

Having same-sex eldest siblings significantly increases the probability to have a third child only for secondary-school graduates (Table III). In this context, the question is whether the instrumental variable estimates of the effect of having more than two children on mothers' labour market participation depend on the mothers' education. The results in Table VI indicate that this is the case. In the sub-sample of college graduates, we do not find any significant effect of fertility on mothers' labour supply. In contrast, for secondary-school graduates, some of the effects 
are negative and significant. Overall, the effect of fertility on mothers’ labour supply, measured using 'same sex' as an instrumental variable, is significant only when the sex of the two eldest siblings affects the probability to have a third child (which is so in the poorly educated case) ${ }^{15}$. These findings are consistent with the assumption that the sex of the two eldest siblings affects the mother's labour supply only insofar as it affects her fertility.

Among secondary-school graduates, having more than two children significantly reduces labour market participation for those who could not benefit from the Allocation parentale d'éducation for their second child whereas it is insignificant for those who could benefit from it. When the second child was born before July 1994, the effect on poorly educated mothers was insignificantly higher than that on the full sample (-0.788 against -0.518 and the standard deviations are close). As anticipated, the effect of having more than two children on mothers' labour supply is significantly negative only when mothers with more than two children had specific incentives to quit the labour market.

Table VI. — Effect of having more than two children on mothers' labour supply according to their level of education

\begin{tabular}{lcccc}
\hline Dependant variable: & \multicolumn{3}{c}{ Labour market participation } \\
\hline Subsamples: & Secondary-school graduates at most & \multicolumn{2}{c}{ College graduates } \\
\hline Estimation technique: & OLS & 2SLS Same sex & OLS & 2SLS Same sex \\
More than 2 children * 2nd child born $>=1994$ & $-0.210^{* * *}$ & -0.722 & -0.061 & 1.527 \\
\multirow{2}{*}{ More than 2 children * 2nd child born $<1994$} & $(0.030)$ & $(0.671)$ & $(0.059)$ & $(2.025)$ \\
& $-0.350^{* * *}$ & $-0.788^{* * *}$ & $-0.286^{* * *}$ & 1.078 \\
\hline$N$ & $(0.010)$ & $(0.278)$ & $(0.021)$ & $(1.001)$ \\
\hline
\end{tabular}

Levels of significance: *: $10 \% * *$ : $5 \% * * *: 1 \%$

Sample: women with a spouse aged 21 to 35 with at least two children and one of the three first children aged less than three.

Note: standard errors (in parentheses) are adjusted for potential serial correlation. Other covariates are age, age at first birth, age difference between the two first siblings (in months), educational level, immigrant status, year-fixed effects and sex of first and second child. Main effect for the Allocation parentale d'éducation (variable "ape2") is included in the equation.

Source: labour force surveys 1990-1998, Insee.

\section{VI.6 Robustness}

We check our results with a falsification test on fathers (Table VII). OLS estimates show that before the reform, fathers with three children did not have a lower labour force participation rate than fathers with two but they worked fewer hours when they were employed. After the reform, fathers with at least three children had a lower labour force participation rate than fathers with two children.

As the conciliation burden mostly rests on women, instrumental variable estimates should not show significant negative effects of fertility on fathers' labour supply. This is confirmed by the results: whatever the date of birth of their second child, the effect of having more than two children on fathers' labour supply is never significantly negative.

15. Because the sex of the two eldest siblings does not affect the fertility decisions of college graduates, the results reported here cannot be interpreted as an evidence that having more than two children has no effect on highly educated mothers' labour supply. 
These results are complementary with those obtained for mothers: when the second child was born before the reform and that having more than two children had a negative impact on mothers' labour market participation, the effect on fathers' labour market participation was significantly positive. After the reform, that is when having more than two children had no impact on mothers' labour market participation, the effect on fathers' labour market participation was also insignificant. Whereas the combined effect of the number of children and of the Allocation parentale d'éducation has a positive effect on fathers' labour market participation (before the reform), the net impact of fertility is insignificant (after the reform).

When the extended sample of mothers aged 21-40 is considered, first stages, ordinary least squares and two-stage least squares results are confirmed and statistical significance levels are identical. For example, having more than two children reduced significantly mothers' labour market participation when the second child was born before the reform ( -0.515 against -0.518 on the 21-35), and the effect was insignificant when he was born after (as on the 21-35).

Table VII. — Effect of Having More than Two Children on Fathers’ Labour Supply

\begin{tabular}{lcccc}
\hline \hline Dependant variable: & \multicolumn{2}{c}{ Labour market participation } & \multicolumn{2}{c}{ Hours / week } \\
\hline Estimation technique: & OLS & 2SLS Same sex & OLS & 2SLS Same sex \\
\hline More than 2 children * 2nd child born $>=1994$ & $-0.023 *$ & 0.168 & 0.76 & 3.86 \\
& $(0.013)$ & $(0.182)$ & $(0.64)$ & $(12.09)$ \\
More than 2 children * 2nd child born $<1994$ & -0.002 & $0.131^{*}$ & $-0.42 * *$ & -0.82 \\
& $(0.02)$ & $(0.071)$ & $(0.19)$ & $(4.50)$ \\
\hline$N$ & 18.522 & 18.522 & 14.480 & 14.480 \\
\hline
\end{tabular}

Levels of significance: *: $10 \% * *: 5 \% * * *: 1 \%$

Sample: men with a spouse aged 21 to 35 with at least two children and one of the three first children aged less than three.

Note: standard errors (in parentheses) are adjusted for potential serial correlation. Other covariates are age, age at first birth, age difference between the two first siblings (in months), educational level, immigrant status, year-fixed effects and sex of first and second child. Main effect for the Allocation parentale d'éducation (variable 'ape2') is included in the equation.

Source: labour force surveys 1990-1998, Insee.

When using employment rates rather than labour force participation rates, results differ. In this case, we study the employment status of mothers (employed vs. unemployed or inactive) rather than their working decision. Having more than two children has no significant effect on mothers' employment probability, whatever the date of birth of the second child. The eligibility for the paid parental leave does not alter the causal effect of fertility on mothers' employment. Employment status implies not only mothers' choice to work but also employers' decision to hire them, and this is exactly what differentiates it from unemployment. Employers have no reason to change their employment behaviour after the reform. Thus, finding no difference before and after the reform seems consistent.

VI.7 The use of Twin Births at the Second Pregnancy as an Instrument

The results are also comforted when the same procedure is followed with the instrument " $t$ wins-2"16 (Table VIII). In this case, the fertility shock is produced by the birth of twins at the second

16. Because the birth of twins is correlated with some individual characteristics of mothers, we only use this strategy to back up our initial results obtained with "same sex". 
pregnancy: "twins-2" equals 1 if the second birth is twin, 0 otherwise. As before, we construct an interaction variable between "twins-2" and "ape2" which equals 1 if the mother had twins at the second pregnancy and if the twins were born after July 1994. The interaction variable between "twins-2" and "no ape2" equals 1 if the mother had twins at the second pregnancy and if the twins were born before July 1994. These interaction variables are used as instruments for the endogenous explanatory variables: "more than two children" * "ape 2 " and "more than two children” * “no ape2”.

Table VIII. — Effect of Having More than Two Children on Mothers’ Labour Supply

\begin{tabular}{lcccc}
\hline Dependant variable: & Labour market participation & \multicolumn{2}{c}{ Hours / week } \\
\hline Estimation technique: & OLS & 2SLS Twins-2 & OLS & 2SLS Twins-2 \\
\hline More than 2 children * 2nd child born $>=1994$ & $-0.174 * * *$ & -0.097 & -0.02 & 3.02 \\
& $(0.028)$ & $(0.061)$ & $(2.37)$ & $(4.02)$ \\
More than 2 children * 2nd child born <1994 & $-0.337 * * *$ & $-0.319 * * *$ & $-0.78^{*}$ & -0.29 \\
& $(0.009)$ & $(0.046)$ & $(0.42)$ & $(1.72)$ \\
\hline$N$ & 23.407 & 23.407 & 7.730 & 7.730 \\
\hline
\end{tabular}

Levels of significance: *: $10 \% * *: 5 \% * * *: 1 \%$

Sample: women with a spouse aged 21 to 35 with at least two children and one of the three first children aged less than three.

Note: standard errors (in parentheses) are adjusted for potential serial correlation. Other covariates are age, age, age at first birth, age difference between the two first siblings (in months), educational level, immigrant status, year-fixed effects and sex of first and second child. Main effect for the Allocation parentale d'éducation (variable "ape2") is included in the equation.

Source: labour force surveys 1990-1998, Insee.

The instrumental variable estimates on labour market participation confirm the results obtained with “same sex". Having more than two children significantly reduced mothers' labour market participation only when the second child was born before the reform (-0.319), whereas the effect was insignificant if he was born afterwards. Moreover, here the difference between the two coefficients $(0.222$ with a standard error of 0.076$)$ is statistically significant at the $1 \%$ level. Beyond the incentives created by the Allocation parentale d'éducation, having more than two children has no negative impact on mothers' labour force participation. Insofar as results are similar with two instruments that provoke two different fertility shocks, the evolution of the effect of fertility on mothers' labour supply cannot be explained by the evolution of parents' observable characteristics or preferences as a result of the reform. There is no reason why after the reform, the characteristics of parents with same-sex siblings should be modified the same way as that of parents who had twins. It is hardly plausible that the observed evolution of the effect of having more than two children on mothers' labour supply comes in fact from a change in the first-stage effect, namely the effect of "same sex" (resp. "twins-2") on the probability of having a third child. Using "twins-2" instrument, estimates on the average number of hours worked are too imprecise to identify the impact of having more than two children before and after the reform.

The dichotomisation of the sample according to mothers' level of education (Appendix III) provides interesting results: college graduates have also been affected by the reform since when their second child was born before 1994, having more than two children reduced significantly their activity. But this effect (-0.232) is lower than that on lower educated (-0.338). If their second child was born after 1994, fertility had no effect on their labour supply. 


\section{VI.8 The Effect of Having More than one Child on Mothers' Labour Supply}

The reform decreased the differences in incentives to quit the labour market between mothers' with two and mothers' with more than two children. Symmetrically, the reform increased the differences between mothers' with one and mothers' with more than one child. To enlarge our result, we evaluate the consequences of the extension of the Allocation parentale d'éducation on the behaviour of mothers with one and those with more than one child (Table IX). In the period 1990-1998, mothers with one child could not benefit from a paid parental leave, whereas from 1994, mothers with two children could benefit from the Allocation parentale d'éducation. As a result, in the period 1990-1994, mothers with one and two children had no particular incentive to quit the labour market, whereas from 1994, mothers with one and two children were confronted with different incentives. As before, if the Allocation parentale d'éducation causes the negative effect of fertility on mothers' labour supply, we should observe an increase in the negative effect of having more than one child on mothers' labour supply after the reform. To study the impact of passing from one to more than one child on mothers' labour supply, we select mothers with at least one child and whose first child (if they had only one) or second child (if they had more than one) is less than three. As before, the sample is not selected on the total number of children which would bias our sample, but on the age of children: as long as the second child is less than three, mothers in our sample can have more than two children.

The results of ols estimations show that the negative effect of having more than one child is lower if the second child was born before the reform than if he was born afterwards. Compared to mothers of one child, mothers with more than one child participated less in the labour market by 16.3 percentage points before the reform and by 31.5 percentage points after.

To identify the causal effect of having more than one child, we use a shock on the second birth, namely twin births at the first pregnancy. Two interaction variables are built: the first one between "more than one child" and "ape2" equals 1 if the mother had a second child and if it was born after July $1994^{17}$; the second one between "more than one child" and "no ape2" equals 1 if the mother had a second child and if it was born before July 1994. The variable "more than one child" is instrumented by the variable "twin-1" in two-stage least squares estimations. The coefficients of the two interaction variables give the effect of having more than one child on mothers' labour supply (compared to having only one) in two different context: whether mothers could (or not) benefit from the Allocation parentale d'éducation for their second child ${ }^{18}$. The comparison of these two coefficients gives the evolution of the effect of having more than one child on mothers' labour supply.

17. This interaction variable equals 0 if she could not benefit from the Allocation parentale d'éducation for her second child, that is if her second child was born before July 1994 or if she only had one child.

18. The only difference with the previous exercise is that instead of having four modalities (having two children and the second was born before July 1994, having two children and the second was born after July 1994, having three children or more and the second was born before July 1994, having three children or more and the second was born after July 1994), we have only three : having one child, having two children or more and the second was born before July 1994, having two children or more and the second was born after July 1994. As a consequence, so that the effect of the Allocation parentale d'éducation can be identified, we remove the variable "ape2" from the covariates. Thus, every coefficient can be interpreted relatively to the situation where mothers had only one child. 
Table IX. — Effect of Having More than One Child on Mothers' Labour Supply

\begin{tabular}{lcccc}
\hline Dependant variable: & \multicolumn{2}{c}{ Labour market participation } & \multicolumn{2}{c}{ Hours / week } \\
\hline Estimation technique: & OLS & 2SLS Twins-1 & OLS & 2SLS Twins-1 \\
\hline More than 1 child * 2nd child born $>=1994$ & $-0.315^{* * *}$ & $-0.399^{* * *}$ & $-2.20^{* * *}$ & $3.77^{*}$ \\
& $(0.008)$ & $(0.070)$ & $(0.31)$ & $(2.19)$ \\
More than 1 child * 2nd child born $<1994$ & $-0.163^{* * *}$ & $-0.271^{* * *}$ & $-1.53^{* * *}$ & 1.01 \\
& $(0.006)$ & $(0.049)$ & $(0.21)$ & $1.32)$ \\
\hline$N$ & 37.217 & 37.217 & 16.501 & 16.501 \\
\hline
\end{tabular}

Levels of significance: *: $10 \% * *: 5 \% * * *: 1 \%$

Sample: women with a spouse aged 21 to 35 with at least one child and one of the two first children aged less than three.

Note: standard errors (in parentheses) are adjusted for potential serial correlation. Other covariates are age, age at first birth, educational

level, immigrant status, year-fixed effects.

Source: labour force surveys 1990-1998, Insee.

The instrumental variable estimates show that the negative effect of having more than one child on mothers' labour supply increased after the reform: before the reform, having a second child caused a reduction of 27.1 percentage points in labour market participation. After the reform, the reduction was 39.9 percentage points. As a result, the reform has worsened the consequences of second births on mothers' labour market participation. The difference between the estimates (which equals $0.128(0.085)$ for labour market participation and 1.58 (2.56) for hours worked) is not statistically significant. Before the reform, mothers with one and mothers with two children were not eligible for the Allocation parentale d'éducation whereas mothers with at least three were. The estimate of the effect of having more than one child on mothers' labour force participation before the reform thus does not give the impact of passing from one to more than one child independently of the Allocation parentale d'éducation, but only the net effect of its extension to parents of two children. In other words, it is not possible to identify the effect of having more than one child in the absence of the paid parental leave.

When the sample is separated according to mothers' level of education (Appendix IV), we obtain symmetrical results to those obtained for the effect of passing from two to more than two children. For secondary-school graduates, having more than one child had a negative impact on their participation in the labour market before the reform. The extension of the Allocation parentale d'éducation increased this negative impact. For college graduates, the birth of a second child before the reform had no consequences on mothers' labour supply; on the contrary, a second birth after the reform significantly decreased mothers' labour market participation (at the $1 \%$ level). The decrease in labour market participation after a second birth is higher for secondary-school graduates at most $(-0.458)$ than for college graduates $(-0.286)$.

\section{Conclusion}

This paper evaluates the consequences of the French paid parental leave in terms of balancing work and family life for mothers by measuring how the extension of the Allocation parentale d'éducation in 1994 altered the effect of the number of children on mothers' labour force participation. First, the negative impact of passing from one to more than one child on mothers' labour supply increased after the reform when mothers with two children had stronger incentives to leave the labour market. Second, the reform created the same incentives for mothers with two and mothers with more than two children. As a result, the negative effect of having more than 
two children disappeared when the second child was born after July 1994. Consequently, whereas before 1994, mothers mainly reduced their labour supply when they had a third child, after 1994, withdrawals occurred from the second birth.

The negative impact of fertility on mothers' labour market participation is higher for secondary-school graduates. Whatever the level of education, the negative impact of passing from one to more than one child increases after the reform and that of passing from two to more than two decreases. Precisely, before the reform, college graduates eventually reduced their labour market participation after the birth of a third child; after the reform, they reduced it as soon as they had a second child. Concerning secondary-school graduates, before the reform, they withdrew from the labour market participation after the birth of a second and a third child; whereas after the reform, all the reduction in their labour market participation occurred after the birth of a second child.

The effect of the number of children on mothers' labour supply is thus partly indirect and comes from financial incentives. The effect of having more than two children on mothers' labour supply was significantly negative precisely when only mothers with more than two children were eligible for the paid parental leave. Also, the negative effect of having more than one child on mothers' labour supply was higher when all mothers with more than one child were eligible for the paid parental leave. The net impact of passing from two to more than two children, purged from the effect of the Allocation parentale d'éducation, on mothers' labour force participation is in fact insignificant. As a result, the Allocation parentale d'éducation does not help mothers to balance work and family life, which supposes that mothers can keep on working while taking care of their children, but rather favours an alternation between professional and family life for eligible mothers.

The negative impact of fertility on mothers' labour force participation is linked to the institutional context. This is coherent with Brewster and Rindfuss's [2000] result suggesting that the negative correlation between fertility and labour force participation can be reduced with the appropriate family policies. In France, the device of the paid parental leave increases the impact of fertility on labour force participation and makes it difficult to simultaneously stimulate the fertility rate and mothers' labour market participation.

\footnotetext{
Acknowledgements: We thank Dominique Goux, Marc Gurgand, Andrea Ichino, Eric Maurin, Carolyn Rose, participants at the eale conference in Amsterdam and at the Paris School of Economics seminar, and two anonymous referees for helpful comments and suggestions.

We are particularly grateful to Pierre Cahuc, Eve Caroli, Roland Rathelot and Laurent Lequien for helpful discussions on earlier drafts.
}

Correspondance : Julie Moschion - Melbourne Institute of Applied Economic and Social Research, Faculty of Business and Economics. The University of Melbourne, Level7, Alan Gilbert Building, 161 Barry Street, Victoria 3010 ; tel : +61 390354784.

E-mail : moschion@unimelb.edu.au 


\section{Appendix}

\section{Effect of Having Same Sex Eldest Siblings on the Probability to Have a Third Child}

\begin{tabular}{|c|c|c|}
\hline \multirow[t]{2}{*}{ Dependent variable: } & \multicolumn{2}{|c|}{ More than 2 children } \\
\hline & 2nd child born >= 1994 & 2nd child born $<1994$ \\
\hline Same sex $*$ 2nd child born > = 1994 & $\begin{array}{l}0.022 * * * \\
(0.006)\end{array}$ & $\begin{array}{r}-0.003 \\
(0.005)\end{array}$ \\
\hline Same sex * 2nd child born < 1994 & $\begin{array}{l}-0.000 \\
(0.000)\end{array}$ & $\begin{array}{l}0.028^{* * *} \\
(0.005)\end{array}$ \\
\hline \multicolumn{3}{|l|}{ Age } \\
\hline $21-25$ & $\begin{array}{l}-0.012^{* * *} \\
(0.003)\end{array}$ & $\begin{array}{l}-0.908 * * * \\
(0.010)\end{array}$ \\
\hline $26-30$ & $\begin{array}{l}-0.005^{* * *} \\
(0.002)\end{array}$ & $\begin{array}{l}-0.453 * * * \\
(0.005)\end{array}$ \\
\hline $31-35$ & ref. & ref. \\
\hline Age at 1st birth & $\begin{array}{l}-0.002 * * * \\
(0.000)\end{array}$ & $\begin{array}{l}-0.104 * * * \\
(0.001)\end{array}$ \\
\hline Age difference between the two first births (months) & $\begin{array}{l}-0.002 * * * \\
(0.000)\end{array}$ & $\begin{array}{l}-0.009 * * * \\
(0.000)\end{array}$ \\
\hline \multicolumn{3}{|l|}{ Educational level } \\
\hline No diploma & $\begin{array}{l}0.006 * * \\
(0.003)\end{array}$ & $\begin{array}{l}-0.017 * \\
(0.009)\end{array}$ \\
\hline Secondary-school dropouts & $\begin{array}{c}-0.002 \\
(0.003)\end{array}$ & $\begin{array}{l}-0.055^{* * *} \\
(0.009)\end{array}$ \\
\hline Secondary-school graduates & $\begin{array}{r}-0.004 \\
(0.003)\end{array}$ & $\begin{array}{l}-0.050^{* * *} \\
(0.010)\end{array}$ \\
\hline Bachelors’ degree & $\begin{array}{l}0.004 \\
(0.003)\end{array}$ & $\begin{array}{l}-0.040^{* * *} \\
(0.010)\end{array}$ \\
\hline Masters' degree and + & ref. & ref. \\
\hline \multicolumn{3}{|l|}{ Year-fixed effects } \\
\hline 1990 & $\begin{array}{l}-0.028 * * * \\
(0.004)\end{array}$ & $\begin{array}{l}-0.165^{* * *} \\
(0.011)\end{array}$ \\
\hline 1991 & $\begin{array}{l}-0.028 * * * \\
(0.004)\end{array}$ & $\begin{array}{l}-0.175^{* * *} \\
(0.010)\end{array}$ \\
\hline 1992 & $\begin{array}{l}-0.028 * * * \\
(0.004)\end{array}$ & $\begin{array}{l}-0.172^{* * *} \\
(0.010)\end{array}$ \\
\hline 1993 & $\begin{array}{l}-0.028 * * * \\
(0.004)\end{array}$ & $\begin{array}{l}-0.162^{* * *} \\
(0.011)\end{array}$ \\
\hline 1994 & $\begin{array}{l}-0.028 * * * \\
(0.004)\end{array}$ & $\begin{array}{l}-0.175^{* * *} \\
(0.010)\end{array}$ \\
\hline 1995 & $\begin{array}{l}-0.033^{* * *} \\
(0.004)\end{array}$ & $\begin{array}{l}-0.108 * * * \\
(0.009)\end{array}$ \\
\hline 1996 & $\begin{array}{l}-0.038 * * * \\
(0.005)\end{array}$ & $\begin{array}{l}-0.043^{* * *} \\
(0.007)\end{array}$ \\
\hline 1997 & $\begin{array}{l}-0.026 * * * \\
(0.006)\end{array}$ & $\begin{array}{c}0.003 \\
(0.007)\end{array}$ \\
\hline 1998 & ref. & ref. \\
\hline Immigrant status & $\begin{array}{r}-0.004 \\
(0.003)\end{array}$ & $\begin{array}{l}-0.037 * * * \\
(0.008)\end{array}$ \\
\hline Sex of the first child & $\begin{array}{l}-0.001 \\
(0.014)\end{array}$ & $\begin{array}{r}-0.002 \\
(0.004)\end{array}$ \\
\hline Sex of the second child & $\begin{array}{l}0.002 \\
(0.014)\end{array}$ & $\begin{array}{c}0.002 \\
(0.004)\end{array}$ \\
\hline Allocation parentale d'éducation & $\begin{array}{l}0.033 * * * \\
(0.004)\end{array}$ & $\begin{array}{l}-0.286 * * * \\
(0.008)\end{array}$ \\
\hline Number of observations & 23.407 & 23.407 \\
\hline
\end{tabular}

Levels of significance: *: $10 \% * *: 5 \% * * *: 1 \%$

Sample: women with a spouse aged 21 to 35 with at least two children and one of the three first children aged less than three.

Note: standard errors (in parentheses) are adjusted for potential serial correlation. Other covariates are age, age at first birth, age difference between the two first siblings (in months), educational level, immigrant status, year-fixed effects and sex of first and second child. Main effect for the Allocation parentale d'éducation (variable "ape2") is included in the equation.

Source: labour force surveys 1990-1998, Insee. 


\section{Effect of Having More than Two Children on Mothers' Labour Supply}

\begin{tabular}{|c|c|c|c|c|}
\hline \multirow{2}{*}{$\begin{array}{l}\text { Dependant variable: } \\
\text { Estimation technique: }\end{array}$} & \multicolumn{2}{|c|}{ Labour market participation } & \multicolumn{2}{|c|}{ Hours / week } \\
\hline & OLS & 2SLS Same sex & OLS & 2SLS Same sex \\
\hline More than 2 children * 2nd child born >=1994 & $\begin{array}{l}-0.174 * * * \\
(0.028)\end{array}$ & $\begin{array}{c}-0.276 \\
(0.602)\end{array}$ & $\begin{array}{r}-0.02 \\
(2.37)\end{array}$ & $\begin{array}{r}4.04 \\
(46.35)\end{array}$ \\
\hline More than 2 children * 2nd child born $<1994$ & $\begin{array}{l}-0.337 * * * \\
(0.009)\end{array}$ & $\begin{array}{l}-0.518^{* *} \\
(0.245)\end{array}$ & $\begin{array}{l}-0.78^{*} \\
(0.42)\end{array}$ & $\begin{array}{r}-10.66 \\
(13.48)\end{array}$ \\
\hline \multicolumn{5}{|l|}{ Age } \\
\hline $21-25$ & $\begin{array}{l}-0.171^{* * *} \\
(0.017)\end{array}$ & $\begin{array}{r}-0.337 \\
(0.223)\end{array}$ & $\begin{array}{c}-0.97 \\
(0.83)\end{array}$ & $\begin{array}{l}-8.51 \\
(10.39)\end{array}$ \\
\hline $26-30$ & $\begin{array}{l}-0.050 * * * \\
(0.009)\end{array}$ & $\begin{array}{r}-0.133 \\
(0.112)\end{array}$ & $\begin{array}{l}0.16 \\
(0.35)\end{array}$ & $\begin{array}{r}-3.80 \\
(5.45)\end{array}$ \\
\hline 31-35 & ref. & ref. & ref. & ref. \\
\hline Age at 1st birth & $\begin{array}{l}0.001 \\
(0.002)\end{array}$ & $\begin{array}{r}-0.018 \\
(0.026)\end{array}$ & $\begin{array}{r}0.04 \\
(0.07)\end{array}$ & $\begin{array}{l}-0.86 \\
(1.24)\end{array}$ \\
\hline Age difference between the two first births (months) & $\begin{array}{l}0.001 * * * \\
(0.000)\end{array}$ & $\begin{array}{l}-0.001 \\
(0.002)\end{array}$ & $\begin{array}{l}0.023^{* * *} \\
(0.006)\end{array}$ & $\begin{array}{l}-0.052 \\
(0.104)\end{array}$ \\
\hline \multicolumn{5}{|l|}{ Educational level } \\
\hline No diploma & $\begin{array}{l}-0.264^{* * *} \\
(0.012)\end{array}$ & $\begin{array}{l}-0.267 * * * \\
(0.014)\end{array}$ & $\begin{array}{l}1.00 * * \\
(0.47)\end{array}$ & $\begin{array}{c}0.33 \\
(1.10)\end{array}$ \\
\hline Secondary-school dropouts & $\begin{array}{l}-0.185^{* * *} \\
(0.012)\end{array}$ & $\begin{array}{l}-0.195^{* * *} \\
(0.019)\end{array}$ & $\begin{array}{l}0.94 * * \\
(0.45)\end{array}$ & $\begin{array}{r}0.08 \\
(1.32)\end{array}$ \\
\hline Secondary-school graduates & $\begin{array}{l}-0.090^{* * *} \\
(0.012)\end{array}$ & $\begin{array}{l}-0.100^{* * *} \\
(0.018)\end{array}$ & $\begin{array}{r}0.36 \\
(0.47)\end{array}$ & $\begin{array}{l}-0.25 \\
(1.06)\end{array}$ \\
\hline Bachelors’ degree & $\begin{array}{r}-0.015 \\
(0.013)\end{array}$ & $\begin{array}{c}-0.022 \\
(0.016)\end{array}$ & $\begin{array}{r}0.39 \\
(0.47)\end{array}$ & $\begin{array}{l}-0.19 \\
(0.92)\end{array}$ \\
\hline Masters' degree and + & ref. & ref. & ref. & ref. \\
\hline \multicolumn{5}{|l|}{ Year-fixed effects } \\
\hline 1990 & $\begin{array}{r}-0.018 \\
(0.016)\end{array}$ & $\begin{array}{r}-0.051 \\
(0.048)\end{array}$ & $\begin{array}{l}1.08 * \\
(0.61)\end{array}$ & $\begin{array}{r}-0.55 \\
(2.47)\end{array}$ \\
\hline 1991 & $\begin{array}{c}-0.026^{*} \\
(0.016)\end{array}$ & $\begin{array}{r}-0.061 \\
(0.050)\end{array}$ & $\begin{array}{r}0.91 \\
(0.62)\end{array}$ & $\begin{array}{l}-0.62 \\
(2.36)\end{array}$ \\
\hline 1992 & $\begin{array}{r}-0.020 \\
(0.015)\end{array}$ & $\begin{array}{r}-0.054 \\
(0.049)\end{array}$ & $\begin{array}{l}0.78 \\
(0.64)\end{array}$ & $\begin{array}{r}-0.69 \\
(2.28)\end{array}$ \\
\hline 1993 & $\begin{array}{r}-0.010 \\
(0.016)\end{array}$ & $\begin{array}{r}-0.043 \\
(0.047)\end{array}$ & $\begin{array}{r}0.84 \\
(0.63)\end{array}$ & $\begin{array}{l}-0.71 \\
(2.37)\end{array}$ \\
\hline 1994 & $\begin{array}{l}0.005 \\
(0.015)\end{array}$ & $\begin{array}{r}-0.030 \\
(0.050)\end{array}$ & $\begin{array}{l}1.32 * * \\
(0.63)\end{array}$ & $\begin{array}{l}-0.22 \\
(2.38)\end{array}$ \\
\hline 1995 & $\begin{array}{l}0.011 \\
(0.015)\end{array}$ & $\begin{array}{l}-0.012 \\
(0.037)\end{array}$ & $\begin{array}{c}0.76 \\
(0.60)\end{array}$ & $\begin{array}{l}-0.43 \\
(1.96)\end{array}$ \\
\hline 1996 & $\begin{array}{r}0.008 \\
(0.014)\end{array}$ & $\begin{array}{r}-0.004 \\
(0.030)\end{array}$ & $\begin{array}{r}0.84 \\
(0.54)\end{array}$ & $\begin{array}{c}0.02 \\
(1.59)\end{array}$ \\
\hline 1997 & $\begin{array}{r}0.013 \\
(0.013)\end{array}$ & $\begin{array}{r}0.011 \\
(0.020)\end{array}$ & $\begin{array}{r}0.02 \\
(0.51)\end{array}$ & $\begin{array}{l}-0.09 \\
(0.75)\end{array}$ \\
\hline 1998 & ref. & ref. & ref. & ref. \\
\hline Immigrant status & $\begin{array}{l}0.119 * * * \\
(0.010)\end{array}$ & $\begin{array}{l}0.112^{* * *} \\
(0.014)\end{array}$ & $\begin{array}{l}1.17^{* *} \\
(0.55)\end{array}$ & $\begin{array}{l}1.11^{*} \\
(0.63)\end{array}$ \\
\hline Sex of the first child & $\begin{array}{c}-0.001 \\
(0.006)\end{array}$ & $\begin{array}{r}-0.002 \\
(0.006)\end{array}$ & $\begin{array}{r}0.140 \\
(0.219)\end{array}$ & $\begin{array}{r}0.126 \\
(0.269)\end{array}$ \\
\hline Sex of the second child & $\begin{array}{r}-0.008 \\
(0.006)\end{array}$ & $\begin{array}{r}-0.008 \\
(0.006)\end{array}$ & $\begin{array}{r}0.074 \\
(0.218)\end{array}$ & $\begin{array}{r}0.122 \\
(0.244)\end{array}$ \\
\hline Allocation parentale d'éducation & $\begin{array}{l}-0.190^{* * *} \\
(0.011)\end{array}$ & $\begin{array}{l}-0.240 * * * \\
(0.077)\end{array}$ & $\begin{array}{r}-0.393 \\
(0.454)\end{array}$ & $\begin{array}{l}-2.333 \\
(2.657) \\
\end{array}$ \\
\hline Number of observations & 23.407 & 23.407 & 7.730 & 7.730 \\
\hline
\end{tabular}

Levels of significance: *: $10 \% * *: 5 \% * * *: 1 \%$

Sample: women with a spouse aged 21 to 35 with at least two children and one of the three first children aged less than three.

Note: standard errors (in parentheses) are adjusted for potential serial correlation. Other covariates are age, age at first birth, age difference between the two first siblings (in months), educational level, immigrant status, year-fixed effects and sex of first and second child. Main effect for the Allocation parentale d'éducation (variable "ape2") is included in the equation.

Source: labour force surveys 1990-1998, Insee. 


\section{Effect of Having More than Two Children on Mothers' Labour Supply According to Their Level of Education - "twins-2"Instrument}

\begin{tabular}{lcccc}
\hline Dependant variable: & \multicolumn{3}{c}{ Labour market participation } \\
\hline Subsamples: & Secondary-school graduates at most & \multicolumn{2}{c}{ College graduates } \\
\hline Estimation technique: & OLS & 2SLS Twins-2 & OLS & 2SLS Twins-2 \\
\hline More than 2 children * 2nd child born $>=1994$ & $-0.210^{* * *}$ & $-0.142^{*}$ & -0.061 & -0.067 \\
& $(0.030)$ & $(0.075)$ & $(0.059)$ & $(0.097)$ \\
More than 2 children * 2nd child born $<1994$ & $-0.350^{* * *}$ & $-0.338^{* * *}$ & $-0.287 * * *$ & $-0.232^{* *}$ \\
& $(0.010)$ & $(0.049)$ & $(0.021)$ & $(0.118)$ \\
\hline$N$ & 18,744 & 18,744 & 4,663 & 4,663 \\
\hline
\end{tabular}

Levels of significance: *: $10 \% * *: 5 \% * * *: 1 \%$

Sample: women with a spouse aged 21 to 35 with at least two children and one of the three first children aged less than three.

Note: standard errors (in parentheses) are adjusted for potential serial correlation. Other covariates are age, age at first birth, age difference between the two first siblings (in months), educational level, immigrant status, year-fixed effects and sex of first and second child. Main effect for the Allocation parentale d'éducation (variable "ape2") is included in the equation.

Source: labour force surveys 1990-1998, Insee.

\section{Effect of Having More than One Child on Mothers' Labour Supply According to their Level of Education}

\begin{tabular}{lcccc}
\hline Dependent variable: & \multicolumn{3}{c}{ Labour market participation } \\
\hline Subsamples: & Secondary-school graduates at most & \multicolumn{2}{c}{ College graduates } \\
\hline Estimation technique: & OLS & 2SLS Twins-1 & OLS & 2SLS Twins-1 \\
\hline More than 1 child * 2nd child born > 1994 & $-0.364^{* * *}$ & $-0.458^{* * *}$ & $-0.178^{* * *}$ & $-0.286^{* * *}$ \\
& $(0.010)$ & $(0.089)$ & $(0.015)$ & $(0.110)$ \\
More than 1 child * 2nd child born $<1994$ & $-0.185^{* * *}$ & $-0.304^{* * *}$ & $-0.101^{* * *}$ & -0.136 \\
& $(0.008)$ & $(0.055)$ & $(0.011)$ & $(0.102)$ \\
\hline$N$ & 28.388 & 28.388 & 8.829 & 8.829 \\
\hline
\end{tabular}

Levels of significance: *: $10 \% * *$ : $5 \% * * *: 1 \%$

Sample: women with a spouse aged 21 to 35 with at least one child and one of the two first children aged less than three. Note: standard errors (in parentheses) are adjusted for potential serial correlation. Other covariates are age, age at first birth, educational level, immigrant status, year-fixed effects.

Source: labour force surveys 1990-1998, Insee.

\section{References}

Afsa, C. (1998): “L’allocation parentale d'éducation : entre politique familiale et politique pour l'emploi”, Insee Première, vol. 569. [218,235]

Angrist, J.D. and W.N. Evans (1998): "Children and Their Parents' Labour Supply: Evidence From Exogenous Variation in Family Size”, American Economic Review, vol. 88, 3, 450-477. [218,219,223,228,230,231]

Bergemann, A. and R.T. Riphahn (2011): "Female Labour Supply and Parental Leave Benefits: The Causal Effect of Paying Higher Transfers for a Shorter Period of Time”, Applied Economics Letters, vol. 18, 1, 17-20. [220]

Berger, E., D. Chauffaut, C. Olm et M.O. Simon (2006): "Les bénéficiaires du complément de libre choix d'activité: une diversité de profils”, Etudes et Résultats, vol. 510. [231,235]

Bernhardt, E.M. (1993): "Fertility and Employment”, European Sociological Review, vol. 9, 1, 25-42. [218,221] 
Boyer, D. (2004): “les pères bénéficiaires de l’APE : révélateurs de nouvelles pratiques paternelles”, Recherches et prévisions, vol. 76, 53-62.[218]

Breton, D. et F. Prioux (2005): “Deux ou trois enfants? Influence de la politique familiale et de quelques facteurs sociodémographiques”, Population, vol. 60, 4, 489-522. [223,226,231]

Brewster, K.L. and R.R. Rindfuss (1996): “Childrearing and Fertility”, Population Development Review, vol. 22, 258-289. [218,221]

Brewster, K.L. and R.R. Rindfuss (2000): “Fertility and Women's Employment in Industrialized Nations”, Annual Review of Sociology, vol. 26, 271-296. [218,221,242]

Choné, P., D. le Blanc et I. Robert-Bobée (2004): “Offre de travail féminine et garde des enfants”, Economie et prévision, vol. 162, 1, 23-50. [221]

Conley, D. (2004): “The 'True' Effect of Sibship Size and Birth Order? Instrumental Variable Estimates from Exogenous Variation in Fertility”, Eastern Sociological Society Annual Meeting, New York, NY, 2/21. [230]

del Boca, D., R. Aaberge, U. Colombino, J. Ermisch, M. Francesconi, S. Pasqua and S. Strøm (2005): "Labour Market Participation of Women and Fertility : the Effect of Social Policies", in Boeri, Del Boca and Pissarides (eds.): Labor Market Participation and Fertility of Women: the Effect of Social Policies, Oxford University Press, UK, 121-264. [218]

Ezzaouali, W. (2003): “L'effet des enfants sur l'offre de travail des mères : cas du Canada”, Mémoire de maîtrise en économie, Université du Québec à Montréal. [218]

Foley, M.C. and G.A. York (2005): “The Effect of Children on Female Labour Supply in the United States From 1950 to 2000”, Miméo. [218]

Heckman, J.J. (1978): “Dummy Endogenous Variables in a Simultaneous Equation System”, Econometrica, vol. 46, 4, 931-959.

Heckman, J.J. and T.E. Macurdy (1985): “A simultaneous equations linear probability model”, The Canadian Journal of Economics, vol. 18, 1, 28-37. [230]

Iacovou, M. (2001): “Fertility and Female Labour Force Participation”, ISER Working Paper, vol. 19. [218]

Lalive, R. and J. Zweimüller (2009): "Does Parental Leave Affect Fertility and Return-to-Work? Evidence from Two Natural Experiments”, Quarterly Journal of Economics, vol. 24, 3, 1363-1402. [220]

Laroque, G. and B. Salanié (2008): “Does Fertility respond to Financial Incentives”, IZA Discussion Paper, vol. 3575. [218,221]

Mahieu, R. (2005): “La PAJE après 18 mois de montée en charge”, Recherches et Prévisions, vol. 82. [219]

Marc, C. (2004): “L’influence des conditions d'emploi sur le recours à l’APE : une analyse économique du comportement d'activité des femmes”, Recherches et Prévisions, vol. 75, 21-38. [220]

Martin, J. (1998): “Politique familiale et travail des mères de famille : perspective historique 1942-1982”, Population, vol. 6, 1119-1152. [219]

Moschion, J. (2009): “Offre de travail des mères en France : l'effet causal du passage de deux à trois enfants”, Economie et statistique, 422, 51-78. [217,219,231,233]

Piketty, T. (2005): "L'impact de l'allocation parentale d'éducation sur l'activité féminine et la fécondité en France, 1982-2002”, in Lefevre C. (Ed.): Histoires de familles, histoires familiales, Les Cahiers de l'Ined. [218,220,222,224,226,227,233,235]

Ronsen, M. and Sundström M. (1999): "Public Policies and the Employment Dynamics among New Mothers - A Comparison of Finland, Norway and Sweden”, Discussion Papers Statistics Norway, vol. 263. [220]

Thevenon, O. (2009) “Increased Women’s Labour Force Participation in Europe: Progress in the Work-Life Balance or Polarization of Behaviours?”, Population 64(2), 235-272. [218, 221] 


\section{University Library}

\section{- M M I N E R VA A gateway to Melbourne's research publications}

Minerva Access is the Institutional Repository of The University of Melbourne

Author/s:

Moschion, J

Title:

Reconciling Work and Family Life: The Effect of the French Paid Parental Leave

Date:

2010

Citation:

Moschion, J. (2010). Reconciling Work and Family Life: The Effect of the French Paid Parental Leave. Annals of Economics and Statistics, 99/100 (99/100), pp.217-217. https:// doi.org/10.2307/41219166.

Persistent Link:

http://hdl.handle.net/11343/127327 